\title{
Resolution of Homoallylic Alcohols Containing Dithioketene Acetal Functionalities. Synthesis of Optically Active $\gamma$-Lactones by a Combination of Chemical and Enzymatic Methods
}

\author{
Yuan-Chi Pai, Jim-Min Fang, ${ }^{*}$ and Shih-Hsiung $\mathrm{Wu}^{\dagger}$ \\ Department of Chemistry, National Taiwan University, and Institute of Biological Chemistry, \\ Academic Sinica, Taipei, Taiwan 106, Republic of China
}

Received March 31, $1994^{\otimes}$

\begin{abstract}
Racemic homoallylic alcohols 1-3 containing dithioketeneacetal functionalities were prepared by addition of aldehydes to the allylic anions of ketene dithioacetals or 2-alkenyl-1,3-dithiane in a regio- and stereoselective manner. Lipase-catalyzed hydrolyses of the corresponding acetates 7-9 afforded optically active alcohols 1-3, which were treated with mercuric chloride to give $\gamma$-lactones such as natural hop lactone, whiskey lactone, and cognac lactone.
\end{abstract}

\section{Introduction}

Many natural products contain $\gamma$-lactone moieties. For example, $\gamma$-propenyl- $\gamma$-lactone is found in hop, ${ }^{1} \beta$-methyl$\gamma$-butyl- $\gamma$-lactones (quercus lactones) are gradients of aged whiskey, ${ }^{2} \beta$-methyl- $\gamma$-pentyl- $\gamma$-lactones are natural flavor components of cognac, ${ }^{3}$ and $\beta$-methyl- $\gamma$-(3-methyl2 -butenyl)- $\gamma$-lactone (eldanolide) is a pheromone of the African sugarcane borer. ${ }^{4}$ We have synthesized such $\gamma$-lactones by hydrolyses of the homoallylic alcohols obtained by condensation of aldehydes with the allylic anions generated from ketene dithioacetals or 2-propenyl1,3-dithiane (4-6). ${ }^{5}$ Advantageously, the reaction is $\gamma$-regioselective and the relative stereochemistry of the $\beta$ - and $\gamma$-substituents in 3 is controlled. Racemic 1-3 can be kinetically resolved using lipase-catalyzed reactions, and the optically active homoallylic alcohols containing dithioketene acetal functionalities can be converted to $\gamma$-lactones such as natural hop lactone, whiskey lactone, and cognac lactone.

\section{Results and Discussion}

The allylic anion generated from the ketene dithioacetal (4 or 5) or the 2-propenyl-1,3-dithiane (6) in THF was treated with a variety of aldehydes to give the homoallylic alcohols 1-3. Compounds 3 had the threo configuration as they were obtained via chairlike sixmembered cyclic transition states. ${ }^{5}$ A number of lipases, such as lipases AP6, MY, AY-30, OF, AK, PS, M-AP10, CE-10, R-10, GC-4, N, and type 1 as well as porcine pancreas lipase were tested in order to resolve the homoallylic alcohols 1 . Acetylation of some homoallylic alcohols (Table 1) can be conducted in the presence of vinyl acetate by catalysis with lipases MY or AY, though

$\dagger$ Institute of Biological Chemistry.

Abstract published in Advance ACS Abstracts, September 1, 1994 (1)

(2) (a) Masuda, M.; Nishimura, K. Phytochemistry 1971, 10, 1401. (b) Masuda, M.; Nishimura, K. Chem. Lett. 1981, 1333. (c) Hoppe, D. Bronneke, A. Tetrahedron Lett. 1983, 24, 1687.

(3) (a) Ortuno, R. M.; Merce, R.; Font, J. Tetrahedron 1987, 43, 4497. (b) Nishimura, K. Chem. Today 1987, 189, 30. (c) Ebata, T.; Mastsumoto, K; Yoshikoshi, H.; Koseki, K.; Kawakami, H.; Matsushita, H. Hetercoycles 1990, 31, 1585.

(4) Kunesch, G.; Zagatti, P.; Lallemand, J. Y.; Debal, A.; Vigneron J. P. Tetrahedron Lett. 1981, 22, 5271.

(5) (a) Fang, J.-M.; Hong, B.-C. Synth. Commun. 1986, 16, 523. (b) Fang, J.-M.; Liao, L.-F.; Hong, B.-C. J. Org. Chem. 1986, 51, 2828. (c) Fang, J.-M.; Hong, B.-C.; Liao, L.-F. J. Org. Chem. 1987, 52, 855

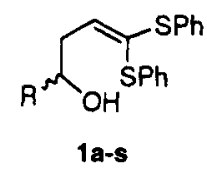

1a $\mathrm{A}=\mathrm{Me}$

$16 \mathrm{~A}=\mathrm{Et}$

16 $R=n-\operatorname{Pr}$

1d $\mathrm{R}=i \mathrm{Pr}$

10 $\mathrm{R}=\mathrm{C}_{6} \mathrm{H}_{5}$

if $\mathrm{R}=\mathrm{O}-\mathrm{MeC}_{6} \mathrm{H}_{4}$

19 $\mathrm{R}=m-\mathrm{MeC}_{6} \mathrm{H}_{4}$

ih $\mathrm{R}=p-\mathrm{MeC}_{6} \mathrm{H}_{4}$

ii $\mathrm{R}=p-(i \mathrm{Pr}) \mathrm{C}_{6} \mathrm{H}_{4}$

1) $\mathrm{R}=0 \mathrm{MeOC} 6 \mathrm{H}_{4}$

1k $\mathrm{R}=m-\mathrm{MeOC}_{6} \mathrm{H}_{4}$

11 $\mathrm{R}=m-\mathrm{CF}_{3} \mathrm{C}_{6} \mathrm{H}_{4}$

im $\mathrm{A}=\mathrm{p}-\mathrm{CF}_{3} \mathrm{C}_{6} \mathrm{H}_{4}$

in $\mathrm{R}=m-\mathrm{FC}_{6} \mathrm{H}_{4}$

10 $R=p-F C_{6} H_{4}$

ip $\mathrm{A}=0 . \mathrm{ClC}_{6} \mathrm{H}_{4}$

1q $\mathrm{R}=m-\mathrm{ClC}_{6} \mathrm{H}_{4}$

ir $\mathrm{R}=m-\mathrm{BrC}_{6} \mathrm{H}_{4}$

is $\mathrm{A}=\mathrm{CH}_{2}=\mathrm{CMe}$

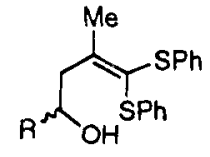

2a-g

2a $\mathrm{R}=\mathrm{Me}$

2b $R=E$

2c $R=n-P r$

2d $R=i P r$

2e $R=C_{6} H_{5}$

2f $\mathrm{R}=n-\mathrm{Bu}$

2g $\mathrm{R}=\pi-\mathrm{C}_{5} \mathrm{H}_{11}$<smiles>[Z15]C(O)C(O)C=C1SCCCS1</smiles>

3a-d

3a $R=E t$

3b $\mathrm{R}=n-\mathrm{Bu}$

3c $\mathrm{A}=n-\mathrm{n}_{5} \mathrm{H}_{11}$

3d $R=n-C_{6} H_{13}$<smiles>[R]C1CC=C([SbH])[Pb]([OH2+])O1</smiles>

7a $\mathrm{R}=\mathrm{Me}$

$7 \mathrm{~b} \mathrm{R}=\mathrm{Et}$

7c $\mathrm{R}=n-\mathrm{Pr}$

7d $\mathrm{R}=i \mathrm{Pr}$

70 $\mathrm{R}=\mathrm{C}_{6} \mathrm{H}_{5}$

$7 \mathrm{R}=\alpha-\mathrm{MeC}_{6} \mathrm{H}_{4}$

$7 \mathrm{~g} R=m-\mathrm{MeC}_{6} \mathrm{H}_{4}$

7h $\mathrm{R}=p-\mathrm{MeC}_{6} \mathrm{H}_{4}$

$71 \mathrm{~A}=p-(i \mathrm{Pr}) \mathrm{C}_{6} \mathrm{H}_{4}$

7) $\mathrm{R}=0-\mathrm{MeOC}{ }_{6} \mathrm{H}_{4}$

$7 \mathrm{~K} \mathrm{~A}=\mathrm{m}-\mathrm{MeOC}_{6} \mathrm{H}_{4}$

$71 \mathrm{R}=m-\mathrm{CF}_{3} \mathrm{C}_{6} \mathrm{H}_{4}$

$7 m \mathrm{~A}=p-\mathrm{CF}_{3} \mathrm{C}_{6} \mathrm{H}_{4}$

7n $\mathrm{R}=m \mathrm{FC}_{6} \mathrm{H}_{4}$

70 $\mathrm{R}=p-\mathrm{FC}_{6} \mathrm{H}_{4}$

$7 p \mathrm{R}=0-\mathrm{ClC}_{6} \mathrm{H}_{4}$

$7 q \mathrm{R}=m-\mathrm{ClC}_{6} \mathrm{H}_{4}$

$7 r \mathrm{R}=m-\mathrm{BrC}_{6} \mathrm{H}_{4}$

7s $\mathrm{R}=\mathrm{CH}_{2}=\mathrm{CMe}$

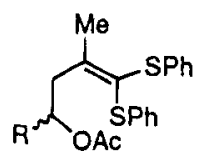

$8 \mathbf{a - g}$

8a $\mathrm{R}=\mathrm{Me}$

$8 b \quad R=E t$

8c $\mathrm{R}=n-\mathrm{Pr}$

8d $R=i P_{r}$

Be $\mathrm{A}=\mathrm{C}_{6} \mathrm{H}_{5}$

Bf $\mathrm{R}=n \mathrm{~B} \mathrm{Bu}$

$8 g \mathrm{R}=n-\mathrm{C}_{5} \mathrm{H}_{11}$

the enantioselectivity was usually low. Acetylations of 1d, 2d, and 2e by catalysis with lipase MY (entries 6 ,

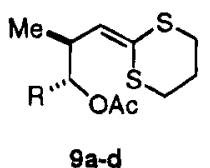

9a $\mathrm{R}=\mathrm{E}$

$9 \mathrm{~b} \mathrm{~A}=n-\mathrm{Bu}$ 9c $\mathrm{R}=n-\mathrm{C}_{5} \mathrm{H}_{11}$
9d $\mathrm{R}=n \mathrm{C}_{6} \mathrm{H}_{13}$ 
Table 1. Acetylation of Homoallylic Alcohols 1 and 2 with Vinyl Acetate in Hexane by Catalysis with Lipases

\begin{tabular}{|c|c|c|c|c|c|c|c|c|c|c|}
\hline entry & $\begin{array}{l}\text { alcohol } \\
\text { substrate }\end{array}$ & $\mathrm{R}=$ & lipase & $\begin{array}{l}\text { reaction } \\
\text { time }(\mathrm{h})\end{array}$ & $\begin{array}{c}\text { conversn } \\
(\%)\end{array}$ & $\begin{array}{l}\text { acetate } \\
\text { product }\end{array}$ & $\begin{array}{l}e e_{p} \\
(\%)\end{array}$ & $\begin{array}{c}\text { confign } \\
\text { of major } \\
\text { enantiomer }\end{array}$ & $\begin{array}{l}\mathrm{ee}_{\mathrm{s}}(\%) \text { of } \\
\text { remaining } \\
\text { substrate }\end{array}$ & $E$ \\
\hline 1 & $1 \mathbf{a}$ & $\mathrm{Me}$ & $\mathrm{MY}$ & 3 & 80 & $7 a$ & 8 & $S$ & 8 & 1.3 \\
\hline 2 & $1 \mathbf{a}$ & $\mathrm{Me}$ & AY & 1 & 50 & $7 \mathbf{a}$ & 6 & $S$ & 6 & 1.2 \\
\hline 3 & $1 b$ & $\mathrm{Et}$ & MY & 13 & 50 & $7 \mathbf{b}$ & 4 & $S$ & 4 & 1.1 \\
\hline 4 & $\mathbf{1 b}$ & Et & $\mathrm{AY}$ & 9 & 50 & $\mathbf{7 b}$ & 12 & $S$ & 26 & 1.5 \\
\hline 5 & $1 \mathrm{c}$ & $n-\operatorname{Pr}$ & MY & 25 & 50 & $7 c$ & 6 & $S$ & 16 & 1.3 \\
\hline 6 & 1d & $i-\operatorname{Pr}$ & $\mathrm{MY}$ & 150 & 20 & $7 d$ & 93 & $R$ & 16 & 32 \\
\hline 7 & $\mathbf{2 a}$ & $\mathrm{Me}$ & $\mathrm{MY}$ & 12 & 50 & $8 \mathbf{a}$ & 40 & $S$ & 40 & 3.3 \\
\hline 8 & $2 a$ & $\mathrm{Me}$ & $\mathrm{AY}$ & 12 & 50 & $8 \mathbf{a}$ & 40 & $\bar{S}$ & 39 & 3.4 \\
\hline 9 & $2 \mathbf{b}$ & Et & MY & 48 & 50 & $8 b$ & 46 & $S$ & 52 & 4.4 \\
\hline 10 & $\mathbf{2 b}$ & $\mathrm{Et}$ & $\mathrm{AY}$ & 48 & 47 & $8 b$ & 69 & $S$ & 69 & 11 \\
\hline 11 & $2 c$ & $n-\operatorname{Pr}$ & MY & 100 & 25 & $8 c$ & 73 & $S$ & 24 & 8 \\
\hline 12 & $2 \mathrm{c}$ & $n-\operatorname{Pr}$ & $\mathrm{AY}$ & 25 & 44 & $8 c$ & 86 & $S$ & 67 & 27 \\
\hline 13 & $\mathbf{2 d}$ & $i-\operatorname{Pr}$ & MY & 150 & 13 & $8 d$ & 96 & $R$ & 22 & 60 \\
\hline 14 & $2 e$ & $\mathrm{C}_{6} \mathrm{H}_{5}$ & $\mathrm{MY}$ & 240 & 10 & $8 \mathbf{e}$ & 98 & $R$ & 15 & 114 \\
\hline
\end{tabular}

Scheme $1^{a}$<smiles>CC(C)=C([SbH])c1ccccc1</smiles>

5<smiles>CCC[C@H](O)CC(C)=C(c1ccccc1)c1ccccc1</smiles>

$($ (R)-2c<smiles>CCCC(O)CC(C)=C(c1ccccc1)c1ccccc1</smiles>

(S)-2c<smiles>CCC[C@H](O)CC(C)=C(c1ccccc1)c1ccccc1</smiles>

$( \pm)-2 c$

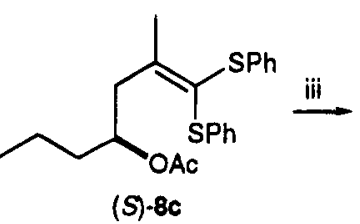<smiles>CCC[C@H](O)CC(C)=O</smiles>

(S) $\cdot(+) \cdot 10$
${ }^{a}$ Key: (i) $\mathrm{BuLi}$, THF, $n-\mathrm{C}_{3} \mathrm{H}_{7} \mathrm{CHO},-78^{\circ} \mathrm{C}, 10 \mathrm{~min}$; $85 \%$; (ii) lipase, vinyl acetate ( 10 equiv), hexane, see Table 1 ; (iii) aqueous $\mathrm{KOH}\left(30 \%\right.$ ), $\mathrm{MeOH}, 25^{\circ} \mathrm{C}, 3 \mathrm{~h} ; 98 \%$; (iv) $\mathrm{O}_{3}, \mathrm{CH}_{2} \mathrm{Cl}_{2},-78^{\circ} \mathrm{C} ; \mathrm{Me}_{2} \mathrm{~S}$, $25^{\circ} \mathrm{C}$.

13 , and $14, \mathrm{R}=i-\mathrm{Pr}$ or $\mathrm{Ph}$ ) were sluggish but gave acetates $\mathbf{7 d}, \mathbf{8 d}$, and $\mathbf{8 e}$ in high optical purity ( $\geq 93 \%$ ee).

Reaction mixture components were separated by silica gel chromatography, and the enantiomeric excess of the remaining substrate, ee $e_{s}$, and the product, ee $e_{p}$, were determined by HPLC using a Chiracel OD column. The $E$ value was calculated according to $E=\ln [1-c(1+$ $\left.\left.e e_{p}\right)\right] / \ln \left[1-c\left(1-e_{p}\right)\right],{ }^{6}$ where conversion, $c$, was deduced from analysis of the reaction mixture by GC, HPLC, or ${ }^{1} \mathrm{H}$ NMR spectroscopy. The acetate $8 \mathrm{c}$ ( $86 \%$ ee), obtained by the lipase-catalyzed reaction (entry 12 , Table 1 ), was saponified and ozonized to give (+)-4-hydroxy-2-heptanone ${ }^{7}$ in favor of the $(S)$-configuration (Scheme 1 ).

Alternatively, lipase-catalyzed hydrolyses of racemic acetates $\mathbf{7}$ and $\mathbf{8}$ were carried out in the presence of cosolvents (Tables 2 and 3 ). The rate of hydrolysis of $7 e$ $(\mathrm{R}=\mathrm{Ph})$ by lipase $\mathrm{MY}$ was adequate using either $\mathrm{DMF}$, hexane, or toluene. The hydrolysis in phosphate buffer (pH 7.5) with 10\% DMF appeared to be superior, giving alcohol 1e in higher enantioselectivity (compare entries 3-5, Table 2).

(6) Chen, C.-J.; Fujimoto, Y.; Girdaukas, G.; Sih, C. J. J. Am. Chem. Soc. 1982, 104, 7294 .

(7) Narasaka, K.; Miwa, T.; Hayashi, H.; Ohta, M. Chem. Lett. 1984, 1399 .
Scheme $2^{a}$<smiles>[R]C(O)C/C=C(\[Sn]c1ccccc1)c1ccccc1</smiles>

(t)-10, $R=P h$

$( \pm)-1 \mathrm{~s}, \mathrm{R}=\mathrm{CH}_{2}=\mathrm{CMe}$

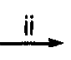<smiles></smiles>

( \pm ) $7 \mathrm{e}, \mathrm{R}=\mathrm{Ph}$

(士)-7s, $\mathrm{R}=\mathrm{CH}_{2}=\mathrm{CMe}$<smiles>[R]C(O)CC=C([SbH])c1ccccc1</smiles>

(R)-10

$($ (R) $-1 \mathrm{~s}$<smiles>[3H][V]</smiles><smiles>[R]C1CCC(=O)O1</smiles>

$(R)-(+)-110, R=P h$

$\left(\right.$ (R) $-(-)-11 \mathrm{~s}, \mathrm{R}=\mathrm{CH}_{2}=\mathrm{CMe}$<smiles>[3H][In]</smiles>

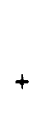<smiles></smiles>

(S)-7e (S)-7s<smiles>[R]C1CCC(=O)O1</smiles>

$(S)-(+)-11$ s

(natural hop lactone)
${ }^{a}$ Key: (i) BuLi, $\mathrm{THF},-78^{\circ} \mathrm{C}, 10 \mathrm{~min}$; $85 \%$; (ii) $\mathrm{Ac}_{2} \mathrm{O}, \mathrm{Et}_{3} \mathrm{~N}$, DMAP cat., $\mathrm{CH}_{2} \mathrm{Cl}_{2}, 25^{\circ} \mathrm{C}, 1 \mathrm{~h} ; 98 \%$; (iii) lipase, DMF, phosphate buffer ( $\mathrm{pH} 7.5$ ); see Table 2; (iv) $\mathrm{HgCl}_{2}$, aqueous $\mathrm{MeOH}$ (10\%), reflux, $5 \mathrm{~h}$; 85\%; (v) aqueous $\mathrm{KOH}(30 \%), \mathrm{MeOH}, 25^{\circ} \mathrm{C}, 3 \mathrm{~h} ; 98 \%$.

Compounds $7 f-r$ containing either electron-donating or electron-withdrawing groups on the phenyl ring were substrates for the lipase-catalyzed reaction. Lipases MY and AY catalyzed the hydrolyses of acetates $7 \mathbf{d}-\mathbf{s}$ in the same stereospecific manner. The major enantiomer of alcohol products $1 \mathrm{~d}-\mathrm{s}$ in each case has the longer retention time on the Chiracel OD column. As delineated in Scheme 2, lipase-catalyzed hydrolyses gave homoallylic alcohols 1e $(\mathrm{R}=\mathrm{Ph})$ and $1 \mathrm{~s}\left(\mathrm{R}=\mathrm{CH}_{2}=\mathrm{CMe}\right)$ in favor of the $(R)$-configuration. Product $1 \mathrm{e}(91 \%$ ee) was treated with $\mathrm{HgCl}_{2}$ to give the optically active $\gamma$-phenyl- $\gamma$-lactone $11 \mathrm{e},{ }^{8}[\alpha]_{\mathrm{D}}+18^{\circ}\left(c=1.1, \mathrm{CHCl}_{3}\right)$. The $(R)$-enantiomer of 
Table 2. Lipase-Catalyzed Hydrolysis of Acetates 7 in Organic Solvent/Phosphate Buffer (pH 7.5) Solution

\begin{tabular}{|c|c|c|c|c|c|c|c|c|c|c|c|}
\hline entry & $\begin{array}{l}\text { acetate } \\
\text { substrate }\end{array}$ & $\mathbf{R}=$ & lipase & $\begin{array}{l}\text { organic } \\
\text { solvent }\end{array}$ & $\begin{array}{l}\text { reaction } \\
\text { time }(\mathrm{h})\end{array}$ & $\begin{array}{c}\text { conversn } \\
(\%)\end{array}$ & $\begin{array}{l}\text { alcohol } \\
\text { product }\end{array}$ & $\begin{array}{l}e e_{p} \\
(\%)\end{array}$ & $\begin{array}{c}\text { confign } \\
\text { of major } \\
\text { enantiomer }\end{array}$ & $\begin{array}{l}\mathrm{ee}_{\mathrm{s}}(\%) \text { of } \\
\text { remaining } \\
\text { substrate }\end{array}$ & $E$ \\
\hline 1 & $7 d$ & $i-\operatorname{Pr}$ & MY & hexane & 240 & 35 & 1d & 95 & $R$ & 50 & 58 \\
\hline 2 & $7 d$ & $i-\operatorname{Pr}$ & MY & DMF & 216 & 42 & 1d & 95 & $R$ & 68 & 72 \\
\hline 3 & $7 e$ & $\mathrm{C}_{6} \mathrm{H}_{5}$ & $\mathrm{MY}$ & hexane & 120 & 37 & le & 79 & $R$ & 45 & 13 \\
\hline 4 & $7 e$ & $\mathrm{C}_{6} \mathrm{H}_{5}$ & MY & toluene & 300 & 50 & le & 75 & $R$ & 99 & 34 \\
\hline 5 & $7 e$ & $\mathrm{C}_{6} \mathrm{H}_{5}$ & $M Y$ & $\mathrm{DMF}$ & 120 & 50 & le & 82 & $R$ & 87 & 33 \\
\hline 6 & $7 e$ & $\mathrm{C}_{6} \mathrm{H}_{5}$ & $\mathrm{AY}$ & $\mathrm{DMF}$ & 168 & 41 & $1 e$ & 91 & $R$ & 64 & 40 \\
\hline 7 & $7 f$ & $o-\mathrm{MeC}_{6} \mathrm{H}_{4}$ & MY & $\mathrm{DMF}$ & 120 & 20 & If & 93 & $R$ & 27 & 35 \\
\hline 8 & $7 g$ & $m-\mathrm{MeC}_{6} \mathrm{H}_{4}$ & MY & $\mathrm{DMF}$ & 130 & 30 & $1 \mathrm{~g}$ & 91 & $R$ & 45 & 33 \\
\hline 9 & $7 \mathrm{~g}$ & $m-\mathrm{MeC}_{6} \mathrm{H}_{4}$ & AY & DMF & 210 & 32 & $1 \mathrm{~g}$ & 87 & $R$ & 47 & 23 \\
\hline 10 & $7 \mathrm{~h}$ & $p-\mathrm{MeC}_{6} \mathrm{H}_{4}$ & $\mathrm{MY}$ & $\mathrm{DMF}$ & 160 & 44 & $1 \mathrm{~h}$ & 87 & $R$ & 71 & 30 \\
\hline 11 & $\mathbf{7 i}$ & $p-(i-\mathrm{Pr}) \mathrm{C}_{6} \mathrm{H}_{4}$ & $\mathrm{MY}$ & $\mathrm{DMF}$ & 288 & 45 & $\overline{1 i}$ & 94 & $R$ & 70 & 64 \\
\hline 12 & $\mathbf{7 j}$ & $o-\mathrm{MeOC}_{6} \mathrm{H}_{4}$ & $M Y$ & $\mathrm{DMF}$ & 120 & 35 & $\mathbf{1 j}$ & 92 & $R$ & 50 & 39 \\
\hline 13 & $7 \mathbf{k}$ & $m-\mathrm{MeOC}_{6} \mathrm{H}_{4}$ & $\mathrm{MY}$ & DMF & 120 & 23 & $\mathbf{1 k}$ & 96 & $R$ & 37 & 70 \\
\hline 14 & 71 & $m-\mathrm{CF}_{3} \mathrm{C}_{6} \mathrm{H}_{4}$ & $\mathrm{MY}$ & DMF & 130 & 40 & 11 & 98 & $R$ & 51 & 164 \\
\hline 15 & 71 & $m-\mathrm{CF}_{3} \mathrm{C}_{6} \mathrm{H}_{4}$ & $\mathrm{AY}$ & DMF & 120 & 20 & 11 & 97 & $R$ & 19 & 79 \\
\hline 16 & $7 \mathrm{~m}$ & $p-\mathrm{CF}_{3} \mathrm{C}_{6} \mathrm{H}_{4}$ & MY & DMF & 144 & 28 & $1 \mathrm{~m}$ & 96 & $R$ & 28 & 70 \\
\hline 17 & $\mathbf{7 n}$ & $m-\mathrm{FC}_{6} \mathrm{H}_{4}$ & MY & DMF & 120 & 38 & 1n & 94 & $R$ & 56 & 57 \\
\hline 18 & 70 & $p-\mathrm{FC}_{6} \mathrm{H}_{4}$ & $\mathrm{MY}$ & DMF & 120 & 40 & 10 & 96 & $R$ & 54 & 113 \\
\hline 19 & $7 p$ & $o-\mathrm{ClC}_{6} \mathrm{H}_{4}$ & $\mathrm{MY}$ & DMF & 130 & 33 & $1 p$ & 98 & $R$ & 47 & 125 \\
\hline 20 & $7 q$ & $m-\mathrm{ClC}_{6} \mathrm{H}_{4}$ & MY & DMF & 120 & 48 & 19 & 97 & $R$ & 84 & 190 \\
\hline 21 & $7 q$ & $m-\mathrm{ClC}_{6} \mathrm{H}_{4}$ & $\mathrm{AY}$ & $\mathrm{DMF}$ & 120 & 42 & 19 & 89 & $R$ & 66 & 34 \\
\hline 22 & $7 \mathbf{r}$ & $m-\mathrm{BrC}_{6} \mathrm{H}_{4}$ & MY & DMF & 310 & 20 & $1 \mathbf{r}$ & 81 & $R$ & 20 & 11 \\
\hline 23 & $7 s$ & $\mathrm{CH}_{2}=\mathrm{CMe}$ & MY & DMF & 120 & 37 & 1s & 82 & $R$ & 42 & 13 \\
\hline 24 & $7 \mathrm{~s}$ & $\mathrm{CH}_{2}=\mathrm{CMe}$ & $\mathrm{AY}$ & DMF & 240 & 55 & 1s & 75 & $R$ & 95 & 222 \\
\hline
\end{tabular}

Table 3. Lipase-Catalyzed Hydrolysis of Acetates 8 in DMF/Phosphate Buffer (pH 7.5) Solution (1:9)

\begin{tabular}{|c|c|c|c|c|c|c|c|c|c|c|}
\hline entry & $\begin{array}{c}\text { acetate } \\
\text { substrate }\end{array}$ & $\mathrm{R}=$ & lipase & $\begin{array}{l}\text { reaction } \\
\text { time }(\mathrm{h})\end{array}$ & $\begin{array}{c}\text { conversn } \\
(\%)\end{array}$ & $\begin{array}{l}\text { alcohol } \\
\text { product }\end{array}$ & $\begin{array}{l}e e_{p} \\
(\%)\end{array}$ & $\begin{array}{c}\text { confign } \\
\text { of major } \\
\text { enantiomer }\end{array}$ & $\begin{array}{l}e_{s}(\%) \text { of } \\
\text { remaining } \\
\text { substrate }\end{array}$ & $E$ \\
\hline 1 & $8 \mathbf{a}$ & $\mathrm{Me}$ & MY & 24 & 50 & $2 a$ & 23 & $S$ & 21 & 2 \\
\hline 2 & $8 a$ & $\mathrm{Me}$ & $\mathrm{AY}$ & 24 & 70 & $\mathbf{2 a}$ & 20 & $S$ & 37 & 4.4 \\
\hline 3 & $\mathbf{8 b}$ & $\mathrm{Et}$ & MY & 120 & 43 & $\mathbf{2 b}$ & 56 & $S$ & 31 & 4 \\
\hline 4 & $\mathbf{8 b}$ & $\mathrm{Et}$ & $\mathrm{AY}$ & 120 & 48 & $\mathbf{2 b}$ & 57 & $S$ & 54 & 6 \\
\hline 5 & $8 c$ & $n-\operatorname{Pr}$ & MY & 120 & 45 & $2 c$ & 61 & $S$ & 40 & 6 \\
\hline 6 & $8 \mathrm{c}$ & $n-\operatorname{Pr}$ & $\mathrm{AY}$ & 120 & 40 & $2 c$ & 65 & $S$ & 36 & 7 \\
\hline 7 & $8 d$ & $i-\operatorname{Pr}$ & MY & 450 & 30 & $2 d$ & 77 & $R$ & 36 & 11 \\
\hline 8 & $8 d$ & $i-\operatorname{Pr}$ & $\mathrm{AY}$ & 360 & 35 & $\mathbf{2 d}$ & 91 & $R$ & 55 & 37 \\
\hline 9 & $8 e$ & $\mathrm{C}_{6} \mathrm{H}_{5}$ & MY & 144 & 47 & $\mathbf{2 e}$ & 66 & $R$ & 53 & 8 \\
\hline 10 & $8 e$ & $\mathrm{C}_{6} \mathrm{H}_{5}$ & $\mathrm{AY}$ & 48 & 25 & $2 e$ & 74 & $R$ & 24 & 8 \\
\hline 11 & $8 f$ & $n-B u$ & MY & 137 & 45 & $2 f$ & 72 & $S$ & 48 & 10 \\
\hline 12 & $8 f$ & $n-B u$ & $\mathrm{AY}$ & 137 & 45 & $2 f$ & 82 & $S$ & 67 & 20 \\
\hline 13 & $8 \mathrm{~g}$ & $n-\bar{C}_{5} \mathrm{H}_{11}$ & MY & 220 & 15 & $2 \mathrm{~g}$ & 97 & $S$ & 21 & 120 \\
\hline 14 & $8 g$ & $n-\mathrm{C}_{5} \mathrm{H}_{11}$ & $\mathrm{AY}$ & 216 & 15 & $\mathbf{2}$ & 99 & $S$ & 12 & 220 \\
\hline
\end{tabular}

Table 4. Lipase-Catalyzed Hydrolysis of Acetates 9 in DMF/Phosphate Buffer (pH 7.5) Solution (1:9)

\begin{tabular}{|c|c|c|c|c|c|c|c|c|c|c|}
\hline entry & $\begin{array}{c}\text { acetate } \\
\text { substrate }\end{array}$ & $\mathrm{R}=$ & lipase & $\begin{array}{l}\text { reaction } \\
\text { time }(\mathrm{h})\end{array}$ & $\begin{array}{c}\text { conversn } \\
(\%)\end{array}$ & $\begin{array}{l}\text { alcohol } \\
\text { product }\end{array}$ & $\begin{array}{l}e e_{p} \\
(\%)\end{array}$ & $\begin{array}{c}\text { confign } \\
\text { of major } \\
\text { enantiomer }\end{array}$ & $\begin{array}{l}\mathrm{ee}_{\mathrm{s}}(\%) \text { of } \\
\text { remaining } \\
\text { substrate }\end{array}$ & $E$ \\
\hline 1 & $9 \mathbf{a}$ & Et & MY & 48 & 40 & $\mathbf{3 a}$ & 88 & $2 S, 3 R$ & 55 & 27 \\
\hline 2 & $9 \mathbf{a}$ & Et & AY & 48 & 38 & $\mathbf{3 a}$ & 91 & $2 S, 3 R$ & 52 & 35 \\
\hline 3 & $9 b$ & $n$-Bu & MY & 70 & 30 & $\mathbf{3 b}$ & 91 & $2 S, 3 R$ & 44 & 33 \\
\hline 4 & $9 b$ & $n-\mathrm{Bu}$ & $\mathrm{AY}$ & 70 & 25 & $\mathbf{3 b}$ & 98 & $2 S, 3 R$ & 35 & 139 \\
\hline 5 & $9 b$ & $n-\mathrm{Bu}$ & $\mathrm{AY}$ & 480 & 53 & $\mathbf{3 b}$ & 85 & $2 S, 3 R$ & 95 & 48 \\
\hline 6 & $9 \mathrm{c}$ & $n-\mathrm{C}_{5} \mathrm{H}_{11}$ & $\mathrm{MY}$ & 144 & 40 & $3 c$ & 85 & $2 S, 3 R$ & 58 & 22 \\
\hline 7 & $9 c$ & $n-\mathrm{C}_{5} \mathrm{H}_{11}$ & $\mathrm{AY}$ & 51 & 37 & $3 c$ & 93 & $2 S, 3 R$ & 65 & 52 \\
\hline 8 & $9 c$ & $n-\mathrm{C}_{5} \mathrm{H}_{11}$ & AY & 240 & 24 & $3 c$ & 96 & $2 S, 3 R$ & 30 & 66 \\
\hline 10 & 9d & $n-\mathrm{C}_{6} \mathrm{H}_{13}$ & MY & 216 & 40 & 3d & 81 & $2 S, 3 R$ & 58 & 17 \\
\hline 10 & $9 d$ & $n-\mathrm{C}_{6} \mathrm{H}_{13}$ & $\mathrm{AY}$ & 216 & 30 & 3d & 94 & $2 S, 3 R$ & 37 & 46 \\
\hline
\end{tabular}

alcohol 1s (95\% ee) was similarly converted to (-)-hop lactone 11s. The natural hop lactone is dextrorotatory ${ }^{1}$ and by these data has the $(\boldsymbol{S})$-configuration.

The combined chemical and enzymatic method was used in an expedient synthesis of a whisky lactone $\mathbf{1 2 b}$ and a cognac lactone 12c containing trans $\beta$ - and $\gamma$-substituents (Scheme 3$)$. The racemic alcohol $\mathbf{3 b}(\mathrm{R}=$ $n-\mathrm{C}_{4} \mathrm{H}_{9}$ ) obtained by condensation of 2-propenyl-1,3dithiane and pentanal was converted to the correspond-

(8) Manzocchi, A.; Rosangela, C.; Fiecchi, A.; Santaniello, E. J. Chem. Soc., Perkin Trans. 1 1987, 2753. ing acetate $\mathbf{9 b}\left(\mathrm{Ac}_{2} \mathrm{O}, \mathrm{Et}_{3} \mathrm{~N}\right)$. Racemic $\mathbf{9 b}$ was subjected to lipase-catalyzed hydrolysis to give the optically active alcohol $\mathbf{3 b}$ having the (2S,3R)-configuration (Table 4). Subsequent treatment with $\mathrm{HgCl}_{2}$ afforded the natural trans quercus lactone 12b. ${ }^{2}$ By a similar procedure, the optically active alcohol $3 \mathrm{c}\left(\mathrm{R}=n-\mathrm{C}_{5} \mathrm{H}_{11}\right)$ was obtained and subsequently transformed into the natural cognac lactone $12 \mathrm{c} .{ }^{3}$ The remaining acetates $(2 R, 3 S)-9 b, c$ were saponified and treated with $\mathrm{HgCl}_{2}$ to give unnatural antipodes of whiskey lactone and cognac lactone.

In summary, we have demonstrated the synthesis of varied optically active alcohols $\mathbf{1}-\mathbf{3}$ via lipase-catalyzed 
<smiles>[R]O[C@H](C)CC=C(Sc1ccccc1)Sc1ccccc1</smiles>

$\mathrm{R}=i \mathrm{Pr}, \mathrm{Ph}$ or $\mathrm{CH}_{2}=\mathrm{CMe}$

(Table 2)<smiles>[Y4][C@]([2H])(CC=C1SCCCS1)[C@@H](C)O</smiles>

$\mathrm{R}=$ ralkyl

(Table 4)

Figure 1. Preferable enantiomers for lipase-catalyzed hydrolyses.

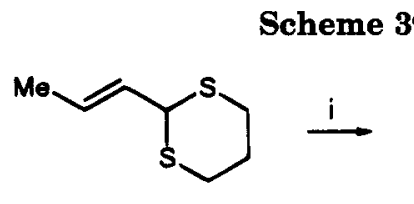

6<smiles>[R]C(O)C(C)C=C1SCCCS1</smiles>

$( \pm)-9 b, c$

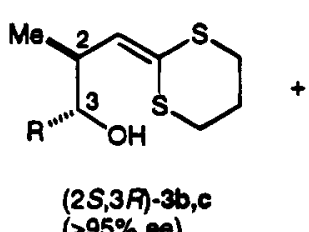<smiles>C[C@@H]1CC(=O)O[C@@H]1P</smiles>

$(4 S, 5 P)-(+)-12 b, R=n-C_{4} H_{8}$ (natural trans quercus lactone) $(4 S, 5 P)-(+)-12 c, R=n-C_{5} H_{11}$ (natural cognac lactone)

${ }^{a} \mathrm{Key}$ : (i) BuLi, THF, $n-\mathrm{C}_{4} \mathrm{H}_{9} \mathrm{CHO}$ or $n-\mathrm{C}_{5} \mathrm{H}_{11} \mathrm{CHO},-78^{\circ} \mathrm{C}, 10$ min; 85\%; (ii) $\mathrm{Ac}_{2} \mathrm{O}, \mathrm{Et}_{3} \mathrm{~N}$, cat. DMAP, $\mathrm{CH}_{2} \mathrm{Cl}_{2}, 25{ }^{\circ} \mathrm{C}, 1 \mathrm{~h} ; 98 \%$; (iii) lipase, DMF, phosphate buffer ( $\mathrm{pH} 7.5$ ), see Table 4; (iv) $\mathrm{HgCl}_{2}$, aqueous $\mathrm{MeOH}(10 \%)$, reflux, $5 \mathrm{~h} ; 92 \%$.

hydrolyses of racemic acetates 7-9. Alcohols 1s, 3b, and $3 \mathbf{c}$ are precursors of natural $\gamma$-lactones. The enantiomeric preference for lipase-catalyzed hydrolyses of $7-9$ are shown in Figure 1. $(R)$-Enantiomers of $7 \mathbf{d}(\mathrm{R}=i$-Pr), 7e-r $\left(\mathrm{R}=\mathrm{XC}_{6} \mathrm{H}_{4}\right)$, and $7 \mathrm{~s}\left(\mathrm{R}=\mathrm{CH}_{2}=\mathrm{CMe}\right)$ were selectively hydrolyzed with $75-98 \%$ ee (Table 2 ). The result indicates a model for the enzymatic hydrolysis. The molecule orients with the bis(phenylthio) group on the left-hand side and the $\mathrm{R}$ group on the right-hand side, while the reacting acetoxy group positions on the front face. A similar orientation of substrates 8 , regardless of the nature of $\mathrm{R}$ groups ( $n$-alkyl, $i-\mathrm{Pr}$, or $\mathrm{Ph}$ ) also accounts for the observed enantioselective hydrolyses (Table 3 ).
Lipase-catalyzed acetylations of alcohols 1 and 2 (Table 1) follow the same trend, i.e., preference for formation of $(R)$-enantiomers of acetates $7 \mathbf{a}, 8 \mathbf{d}$, and $8 \mathbf{e}(\mathrm{R}=i$-Pr or $\mathrm{Ph})$ and $(S)$-enantiomers of 7a-c and 8a-c $(\mathrm{R}=n$-alkyl). Lipase-catalyzed hydrolysis of $\mathbf{9}$, however, appears to favor the $(2 S, 3 R)$-enantiomer having the molecule oriented as shown in Figure 1. From the literature, alcohols containing sulfanyl or sulfonyl groups have been resolved by enzymatic methods. Several models ${ }^{10}$ have been proposed to interpret enantioselectivity in lipasecatalyzed reactions, though no single model can fit all the experimental results.

\section{Experimental Section}

The ${ }^{1} \mathrm{H}$ NMR spectra were recorded at 200 or $300 \mathrm{MHz}$ using tetramethylsilane as internal standard. ${ }^{13} \mathrm{C}$ NMR spectra were recorded at 50 or $75 \mathrm{MHz}$. The mass spectra were recorded at an ionizing voltage of 70 or $20 \mathrm{eV}$. HPLC was carried out on a chromatograph using a $\mu$-Porasil column $(7 \mu \mathrm{m}, 25 \mathrm{~cm} \times$ $0.78 \mathrm{~cm}$ ) with a $5 \mathrm{~mL} / \mathrm{min}$ flow rate of elution. Enantiomeric excess of the remaining substrate, $e_{s}$, and the product, ee were determined by HPLC using a Chiracel OD column $(0.46$ $\mathrm{cm}$ i.d. $\times 25 \mathrm{~cm}$ ) with $1 \mathrm{~mL} / \mathrm{min}$ flow rate of elution. The $E$ value was calculated according to $E=\ln \left[1-c\left(1+e e_{p}\right)\right] / \ln [1$ $\left.-c\left(1-e_{p}\right)\right],{ }^{6}$ where $c$ is conversion.

Lipase AP6 (Aspergillus niger), lipase PS (Pseudomonas sp.), lipase N (Rhizopus niveus), lipase F-AP15 (Rhizopus oryzae), lipase AY-30 (Candida cylindracea), lipase CE-10 (Humicola sp.), lipase GC-4 (Geotrichum candidum), lipase R-10 (Penicillium roqueforti), lipase AK (Pseudomonas sp.), and lipase M-AP10 (Mucor meihei), were purchased from Amano Pharm. ipase OF (C. cylindracea) and lipase MY (C. cylindracea) were from Meito-Sangyo Co., Ltd, Japan. Porcine pancreas lipase (PPL) and lipase type 1 (wheat) were from Sigma, USA. These crude enzymes were used for enzymatic reactions without further purification.

General Procedure for Synthesis of Racemic Homoallylic Alcohols 1-3 and Their Acetates 7-9. Under an atmosphere of nitrogen, butyllithium $(4.3 \mathrm{~mL}$ of $1.6 \mathrm{M}$ solution in hexane) was added drop by drop to a cold $\left(-20^{\circ} \mathrm{C}\right) \mathrm{THF}$ $(10 \mathrm{~mL})$ solution of dithioketene acetal or dithiane $(5 \mathrm{mmol}$, 4,5 , or 6). The mixture was stirred for $30 \mathrm{~min}$ and cooled to $-78^{\circ} \mathrm{C}$, and a THF $(2 \mathrm{~mL})$ solution of the appropriate aldehyde $(6 \mathrm{mmol})$ was added drop by drop. The mixture was stirred for $10 \mathrm{~min}$ and quenched by addition of a solution of acetic acid $(0.9 \mathrm{~mL}, 15 \mathrm{mmol})$ in THF $(2 \mathrm{~mL})$. The mixture was washed with saturated $\mathrm{NaHCO}_{3}$ and extracted three times with EtOAc. The combined EtOAc extracts were washed with brine, dried $\left(\mathrm{Na}_{2} \mathrm{SO}_{4}\right)$, and concentrated under reduced pressure. The residue was chromatographed on a silica gel column by elution with gradients of EtOAc in hexane (10-20\%) to give homoallylic alcohols $1-3$ in $85-95 \%$ yields.

Triethylamine $(10 \mathrm{mmol})$ and acetic anhydride $(16 \mathrm{mmol})$ were added to a cold $\left(0^{\circ} \mathrm{C}\right)$ solution of the homoallylic alcohol

(9) (a) Fuganti, C.; Grasselli, P.; Servi, S.; Lazzarine, A.; Casati, P. Tetrahedron 1988, 44, 2575. (b) Bianchi, D.; Cesti, P.; Golini, P. Tetrahedron 1989, 45, 869. (c) Gu, R. L.; Sih, C. J. Tetrahedron Lett. 1990, 31, 3283. (d) Jacobs, H. K.; Mueller, B. H.; Gopalan, A. S. Tetrahedron 1992, 48, 8891. (e) Goergens, U.; Schneider, M. P. Tetrahedron Asymmetry 1992, 3, 1149. (f) Oyama, K.; Nishimura, S.; Nonaka, Y.; Kihara, K.; Hashimoto, T. J. Org. Chem. 1981, 46, 5242. (g) Isowa, Y.; Ohmori, M.; Ichikawa, T.; Mori, K. Tetrahedron Lett. 1979, 2611. (h) Sakina, K.; Kawazura, K.; Morihara, K.; Tajima, H. Chem. Pharm. Bull.1988, 36, 4345. (i) Matos, J. R.; West, J. B.; Wong, C.-H. Biotechnol. Lett. 1987, 9, 233.

(10) (a) Oberhauser, T.; Faber, K.; Griengl, H. Tetrahedron 1989 45, 1679. (b) Roberts, S. M. Phill. Trans. R. Soc. London B 1989, 45 1679. (c) Xie, Z.-F.; Suemune, H.; Sakai, K. Tetrahedron Asymmetry 1990 1, 395. (d) Burgess, K.; Jennings, L. D. J. Am. Chem. Soc. 1990 112, 7434. (e) Kazlauskai, R. J.; Weissfoch, A. N. E.; Rappaport, A. T. Cuccia, L. A. J. Org. Chem. 1991, 56, 2656 and references cited therein. (f) Burgess, K.; Jennings, L. D. J. Am. Chem. Soc. 1991, 113, 6129. (g) Kim, M.-J.; Cho, H. J. Chem. Soc., Chem. Commun. 1992, 1411. (h) O'Hagan, D.; Zaid, N. A. J. Chem. Soc., Perkin Trans. 1 1992, 947. (i) Wimmer, Z. Tetrahedron 1992, 48, 8431. (j) Takano, S.; Yamane, T. Takahashi, M.; Ogasawara, K. Tetrahedron Asymmetry 1992, 3, 837. 
(4 mmol) and a small amount of 4-(dimethylamino)pyridine $(10 \mathrm{mg})$ in $\mathrm{CH}_{2} \mathrm{Cl}_{2}(10 \mathrm{~mL})$. The mixture was stirred for $1 \mathrm{~h}$, concentrated, diluted with brine, and extracted with EtOAc. The organic phase was dried $\left(\mathrm{Na}_{2} \mathrm{SO}_{4}\right)$, concentrated, and purified on a silica gel column by elution with gradients of EtOAc in hexane $(3-10 \%)$ to give the corresponding acetates 7-9 in $90-98 \%$ yields.

General Procedure for Lipase-Catalyzed Acetylation of Homoallylic Alcohols 1 and 2. The alcohol ( $1 \mathrm{mmol}$ ) was stirred $(800-1000 \mathrm{rpm})$ with vinyl acetate $(10 \mathrm{mmol})$ and a lipase $(0.3 \mathrm{~g})$ in hexane $(5 \mathrm{~mL})$ at room temperature $(25-27$ $\left.{ }^{\circ} \mathrm{C}\right)$. An aliquot of the reaction mixture was occasionally taken and filtered, and the filtrate was analyzed by GC, HPLC, or ${ }^{1} \mathrm{H}$ NMR to determine the conversion. After the mixture was stirred for the period indicated in Table 1, 30-55\% of the alcohol was converted to the corresponding acetate. The mixture was filtered, and the filtrate was concentrated and chromatographed on a silica gel column by elution with gradients of EtOAc in hexane (3-15\%) to give optically active acetate and alcohol. Enantiomeric excess of the remaining alcohol was determined by HPLC using a Chiracel OD column with elution of 2-propanol in hexane $(0.5-10 \%)$. In order to determine the optical purity of the product, the acetate was converted to the corresponding alcohol by saponification in aqueous $\mathrm{KOH}(30 \%, 1 \mathrm{~mL}) / \mathrm{MeOH}(10 \mathrm{~mL})$ at room temperature for $3 \mathrm{~h}$. The optical purity of the alcohol was similarly determined by HPLC, and its value was taken as that of the acetate.

General Procedure for Lipase-Catalyzed Hydrolysis of Racemic Acetates 7-9. The acetate ( $1 \mathrm{mmol}$ ) and a lipase $(0.3 \mathrm{~g})$ in a mixed solvent of DMF $(0.8 \mathrm{~mL})$ and phosphate buffer $(7.2 \mathrm{~mL}, \mathrm{pH} 7.5)$ were stirred (800-1000 rpm) at room temperature $\left(25-27^{\circ} \mathrm{C}\right)$ for the period indicated in Tables 2-4 to reach $30-55 \%$ conversion. The mixture was filtered, and the filtrate was analyzed by GC, HPLC, or ${ }^{1} \mathrm{H}$ NMR to determine the percent conversion to product. The alcohol products $1-3$ and the starting materials $7-9$ were separated by chromatography, and their values of optical purity were determined by HPLC as described above. In the entries 1, 3, and 4 of Table 2 , the ratio of cosolvent hexane (or toluene) to phosphate buffer was 1:3.

The physical and spectral data of 3-6 were previously reported. ${ }^{5,11}$

5,5-Bis(phenylthio)-4-penten-2-ol (1a): oil; TC (15\% EtOAc in hexane) $R_{f}=0.25$; IR (neat) $3355 \mathrm{~cm}^{-1} ; \mathrm{MS} \mathrm{m} / z$ (rel intensity) $302\left(\mathrm{M}^{+}, 100\right), 257(90)$; ${ }^{1} \mathrm{H} \mathrm{NMR}\left(\mathrm{CDCl}_{3}\right) \delta 7.28-$ $7.18(10 \mathrm{H}, \mathrm{m}), 6.37(1 \mathrm{H}, \mathrm{t}, J=7.4 \mathrm{~Hz}), 3.90(1 \mathrm{H}, \mathrm{dq}, J=6.2$, $6.0 \mathrm{~Hz}), 2.60(2 \mathrm{H}, \mathrm{dd}, J=7.2,7.8 \mathrm{~Hz}), 1.21(3 \mathrm{H}, \mathrm{d}, J=6.2$ $\mathrm{Hz}) ;{ }^{13} \mathrm{C}$ NMR $\left(\mathrm{CDCl}_{3}\right) \delta 138.6(\mathrm{~d}), 136.0(\mathrm{~s}), 135.0(\mathrm{~s}), 133.9$ (s), 131.6 (d, 2 C), 130.4 (d, 2 C), 128.8 (d, 2 C), 128.7 (d, 2 C), 127.4 (d), 126.8 (d), 67.4 (d), 40.6 (t), 23.2 (q); HRMS calcd for $\mathrm{C}_{17} \mathrm{H}_{18} \mathrm{OS}_{2}\left(\mathrm{M}^{+}\right) 302.0799$, found 302.0801; HPLC (Chiracel OD, 2-propanol/hexane (3:97)) $t_{\mathrm{R}} 15.8 \mathrm{~min}$ ( $R$-isomer), $18.7 \mathrm{~min}$ (S-isomer).

6,6-Bis(phenylthio)-5-hexen-3-ol (1b): oil; ${ }^{13} \mathrm{C}$ NMR $\left(\mathrm{CDCl}_{3}\right) \delta 139.3(\mathrm{~d}), 134.0(\mathrm{~s}, 2 \mathrm{C}), 131.6(\mathrm{~d}, 2 \mathrm{C}), 131.5(\mathrm{~s})$, 130.4 (d, 2 C), 128.8 (d, 2 C), 128.7 (d, 2 C), 127.4 (d), 126.8 (d), $72.7(\mathrm{~d}), 38.6(\mathrm{t}), 30.0(\mathrm{t}), 9.5(\mathrm{q})$; HRMS caled for $\mathrm{C}_{18} \mathrm{H}_{20^{-}}$ $\mathrm{OS}_{2}\left(\mathrm{M}^{+}\right) 316.0955$, found 316.0955; HPLC (Chiracel OD, 2-propanol/hexane (3:97)) $t_{\mathrm{R}} 18.7 \mathrm{~min}$ ( $R$-isomer), $21.9 \mathrm{~min}(S$ isomer).

1,1-Bis(phenylthio)-1-hepten-4-ol (1c): oil; ${ }^{13} \mathrm{C}$ NMR $\left(\mathrm{CDCl}_{3}\right) \delta 139.3(\mathrm{~d}), 134.0(\mathrm{~s}, 2 \mathrm{C}), 131.6(\mathrm{~d}, 4 \mathrm{C}), 130.4(\mathrm{~d})$, 128.8 (d, 2 C), 128.7 (d), 127.4 (d), 126.8 (d), 71.0 (d), $39.3(\mathrm{t})$, 39.1 (t), 18.7 (q); HRMS calcd for $\mathrm{C}_{19} \mathrm{H}_{22} \mathrm{OS}_{2}\left(\mathrm{M}^{+}\right) 330.1112$ Found 330.1118; HPLC (Chiracel OD, 2-propanol/hexane (5: 95)) $t_{\mathrm{R}} 11.9 \mathrm{~min}(R$-isomer), $14.5 \mathrm{~min}$ ( $S$-isomer).

6,6-Bis(phenylthio)-2-methyl-5-hexen-3-ol (1d): oil; ${ }^{13} \mathrm{C}$ NMR $\left(\mathrm{CDCl}_{3}\right) \delta 140.1$ (d), 134.0 (s), 131.4 (s), 130.9 (s), 130.4 (d, 2C), 128.7 (d, 2 C), 128.6 (d, 2 C), 127.3 (d), 126.7 (d), 76.1 (d), 36.2 (t), 33.5 (d), 18.7 (q), 17.2 (q); HRMS calcd for $\mathrm{C}_{19} \mathrm{H}_{22^{-}}$

(11) (a) Dziadulewicz, E.; Hodgson, D.; Gallagher, T. J. Chem. Soc., Perkin Trans. 1 1988, 3367. (b) Kolb, M. Synthesis 1990, 171.
$\mathrm{OS}_{2}\left(\mathrm{M}^{+}\right) 330.1112$, found 330.1112; HPLC (Chiracel OD, 2-propanol/hexane (10:90)) $t_{\mathrm{R}} 8.1 \mathrm{~min}(S$-isomer), $10.7 \mathrm{~min}(R$ isomer).

4,4-Bis (phenylthio)-1-phenyl-3-butenol (1e): oil; ${ }^{13} \mathrm{C}$ NMR $\left(\mathrm{CDCl}_{3}\right) \delta 143.4(\mathrm{~s}), 138.0$ (d), $134.0(\mathrm{~s}), 133.8(\mathrm{~s}), 131.7(\mathrm{~d}, 2$ C), $130.4(\mathrm{~d}, 2 \mathrm{C}), 128.8$ (d, 4 C), 128.6 (s), 128.5 (d, 2 C), 127.6 (d), 127.4 (d), 126.8 (d), 125.8 (d, 2 C), 75.6 (d), 40.6 (t); HRMS calcd for $\mathrm{C}_{22} \mathrm{H}_{20} \mathrm{OS}_{2}\left(\mathrm{M}^{+}\right) 364.0956$, found 364.0961 ; HPLC (Chiracel OD, 2-propanol/hexane (10:90)) $t_{\mathrm{R}} 15.9 \mathrm{~min}(S-$ isomer), $17.4 \mathrm{~min}$ ( $R$-isomer).

4,4-Bis(phenylthio)-1-(o-methylphenyl)-3-butenol (1f): oil; ${ }^{13} \mathrm{C} \mathrm{NMR}\left(\mathrm{CDCl}_{3}\right) \delta 141.5(\mathrm{~s}), 138.2(\mathrm{~d}), 134.4(\mathrm{~s}), 134.1$ (s), 134.0 (s), 133.7 (s), 131.8 (d, 2 C), 130.4 (d), 130.3 (d, 2 C), 128.8 (d, 2 C), 128.6 (d, 2 C), 127.4 (d), 127.3 (d), 126.7 (d), 126.3 (d), 125.3 (d), 70.0 (d), 39.3 (t), 19.0 (q); HRMS calcd for $\mathrm{C}_{23} \mathrm{H}_{22} \mathrm{OS}_{2}\left(\mathrm{M}^{+}\right) 378.1112$, found 378.1086; HPLC (Chiracel OD, 2-propanol/hexane (20:80)) $t_{\mathrm{R}} 5.9 \mathrm{~min}(S$-isomer), $9.6 \mathrm{~min}$ $(R$-isomer).

4,4-Bis (phenylthio)-1-(m-methylphenyl)-3-butenol (1g): oil; ${ }^{13} \mathrm{C} \mathrm{NMR}\left(\mathrm{CDCl}_{3}\right) \delta 143.4(\mathrm{~s}), 138.4(\mathrm{~s}), 138.0(\mathrm{~s}), 134.0$ (s), $133.8(\mathrm{~s}), 131.6(\mathrm{~d}, 2 \mathrm{C}), 130.3(\mathrm{~d}, 2 \mathrm{C}), 128.7(\mathrm{~d}, 2 \mathrm{C}), 128.6(\mathrm{~d}$, 2 C), $128.3(\mathrm{~d}, 2 \mathrm{C}), 127.3$ (d, 2 C), 126.7 (d), 126.4 (d), 122.9 (d), 73.5 (d), 40.5 (t), 21.4 (q), 14.1 (q); HRMS calcd for $\mathrm{C}_{23} \mathrm{H}_{22}$ $\mathrm{OS}_{2}\left(\mathrm{M}^{+}\right)$378.1112, found 378.1112; HPLC (Chiracel OD, 2-propanol/hexane (10:90)) $t_{\mathrm{R}} 9.3 \mathrm{~min}(S$-isomer $), 10.5 \mathrm{~min}(R$ isomer).

4,4-Bis(phenylthio)-1-(p-methylphenyl)-3-butenol (1h): oil; ${ }^{13} \mathrm{C} \mathrm{NMR}\left(\mathrm{CDCl}_{3}\right) \delta 140.5$ (s), 138.6 (d), 137.2 (d), 135.9 (s), 135.6 (s), 134.0 (s), 133.8 (s), 131.6 (d, 2 C), 131.5 (d, 2 C), 128.9 (d), 128.7 (d, 2 C), 128.5 (d, 2 C), 127.3 (d), 126.7 (d), 125.8 (d, 2 C), 73.4 (d), 40.1 (t), 21.0 (q); HRMS calcd for $\mathrm{C}_{23} \mathrm{H}_{22}$ $\mathrm{OS}_{2}\left(\mathrm{M}^{+}\right)$378.1112, found 378.1112; HPLC (Chiracel OD, 2-propanol/hexane (10:90)) $t_{\mathrm{R}} 14.8 \mathrm{~min}(S$-isomer), $17.6 \mathrm{~min}$ ( $R$-isomer).

4,4-Bis (phenylthio)-1-(p-(methylethyl)phenyl)-3-butenol (1i): oil; ${ }^{13} \mathrm{C}$ NMR $\left(\mathrm{CDCl}_{3}\right) \delta 148.4(\mathrm{~s}), 140.9$ (d), 138.3 (d), 134.0 (d), 133.8 (d), 131.7 (d, 2 C), 131.7 (s), 130.4 (d, 2 C), 128.7 (d, 2 C), 128.6 (d, 2 C), 127.4 (d), 126.7 (d), 126.5 (d, 2 C), 125.8 (d, 2 C), 73.5 (d), 40.5 (t), 33.8 (d), 24.0 (q, 2 C); HRMS calcd for $\mathrm{C}_{25} \mathrm{H}_{26} \mathrm{OS}_{2}\left(\mathrm{M}^{+}\right)$406.1425, found 406.1419; HPLC (Chiracel OD, 2-propanol/hexane (20:80)) $t_{\mathrm{R}} 10.4 \mathrm{~min}(S$ isomer), $14.0 \mathrm{~min}$ ( $R$-isomer).

4,4-Bis(phenylthio)-1-(o-methoxyphenyl)-3-butenol (1j): oil; ${ }^{13} \mathrm{C} \mathrm{NMR}\left(\mathrm{CDCl}_{3}\right) \delta 156.5(\mathrm{~s}), 139.8(\mathrm{~d}), 134.3(\mathrm{~s}), 134.1(\mathrm{~s})$, 131.5 (d, 2 C), $131.2(\mathrm{~s}), 131.0$ (s), 130.3 (d, 2 C), 128.7 (d, 2 C) 128.6 (d, 2 C), 128.5 (d), 127.2 (d), 127.1 (d), 126.6 (d), 120.8 (d), 110.6 (d), 70.6 (d), 55.3 (q), 39.0 (t); HRMS calcd for $\mathrm{C}_{23} \mathrm{H}_{22} \mathrm{O}_{2} \mathrm{~S}_{2}\left(\mathrm{M}^{+}\right) 394.1061$, found 394.1067; HPLC (Chiracel OD, 2-propanol/hexane (5:95)) $t_{\mathrm{R}} 14.4 \mathrm{~min}$ ( $S$-isomer), $18.4 \mathrm{~min}$ ( $R$-isomer).

4,4-Bis(phenylthio)-1-(m-methoxyphenyl)-3-butenol (1k): oil; ${ }^{13} \mathrm{C} \mathrm{NMR}\left(\mathrm{CDCl}_{3}\right) \delta 159.8$ (s), 145.2 (s), 138.0 (d), 134.0 (s), 133.8 (s), 132.0 (s), 131.8 (d, 2 C), 130.4 (d, 2 C), 129.5 (d), 128.8 (d, 2 C), 128.7 (d, 2 C), 127.4 (d), 126.8 (d), 118.2 (d), 113.3 (d), 11.3 (d), 73.6 (d), 55.2 (q), 40.5 (t); HRMS calcd for $\mathrm{C}_{23} \mathrm{H}_{22} \mathrm{O}_{2} \mathrm{~S}_{2}\left(\mathrm{M}^{+}\right)$394.1061, found 394.1070; HPLC (Chiracel OD, 2-propanol/hexane (10:90)) $t_{\mathrm{R}} 13.7 \mathrm{~min}$ ( $S$-isomer), 15.6 $\min (R$-isomer).

4,4-Bis(phenylthio)-1 -(m-(trifluoromethyl)phenyl)-3butenol (11): oil; ${ }^{13} \mathrm{C} \mathrm{NMR}\left(\mathrm{CDCl}_{3}\right) \delta 144.5$ (d), 136.0 (d), 135.7 (s) $133.3(\mathrm{~s}), 133.0(\mathrm{~s}), 132.1(\mathrm{~d}, 2 \mathrm{C}), 131.0$ (s), $130.3(\mathrm{~d}, 2 \mathrm{C})$, 129.2 (d), 128.9 (d, 3 C), 128.7 (d, 2 C), 127.7 (d), 126.9 (d), 124.3 (d), 122.6 (d), 72.9 (d), 40.5 (t); HRMS calcd for $\mathrm{C}_{23} \mathrm{H}_{19} \mathrm{~F}_{3^{-}}$ $\mathrm{OS}_{2}\left(\mathrm{M}^{+}\right)$432.0829, found 432.0838; HPLC (Chiracel OD, 2-propanol/hexane (10:90)) $t_{\mathrm{R}} 6.4 \mathrm{~min}(S$-isomer $), 10.4 \mathrm{~min}(R$ isomer).

4,4-Bis(phenylthio)-1-(p-(trifluoromethyl)phenyl)-3butenol (1m): oil; ${ }^{13} \mathrm{C}$ NMR $\left(\mathrm{CDCl}_{3}\right) \delta 147.4$ (s), 135.9 (d), 133.7 (s), 133.4 (s), 133.1 (s), 132.2 (d, 2 C), 130.4 (d, 2 C), 126.9 (d), 126.2 (d), 125.5 (d), 125.1 (d), 125.2 (d), 72.9 (d), 40.5 (t); HRMS calcd for $\mathrm{C}_{23} \mathrm{H}_{19} \mathrm{~F}_{3} \mathrm{OS}_{2}\left(\mathrm{M}^{+}\right) 432.0829$, found 432.0834; HPLC (Chiracel OD, 2-propanol/hexane (20:80)) $t_{\mathrm{R}} 12.3 \mathrm{~min}$ ( $S$-isomer), $15.8 \mathrm{~min}$ ( $R$-isomer).

4,4-Bis(phenylthio)-1-(m-fluorophenyl)-3-butenol (1n): oil; ${ }^{13} \mathrm{C} \mathrm{NMR}\left(\mathrm{CDCl}_{3}\right) \delta 164.5(\mathrm{~s}), 146.1,136.6,136.1,135.7$, $133.9,133.5,132.8,132.1,130.4,130.1,130.0,128.9,128.7$, 
$128.6,127.7,126.9,121.4,114.6,114.3,112.9,112.7,73.0$ (d), 40.5 (t); HRMS calcd for $\mathrm{C}_{22} \mathrm{H}_{19} \mathrm{OS}_{2} \mathrm{~F}\left(\mathrm{M}^{+}\right) 382.0861$, found 382.0844; HPLC (Chiracel OD, 2-propanol/hexane $(20: 80)$ ) $t_{\mathrm{R}}$ $7.4 \mathrm{~min}$ ( $S$-isomer), $11.1 \mathrm{~min}$ ( $R$-isomer).

4,4-Bis(phenylthio)-1-(p-fluorophenyl)-3-butenol (1o): oil; ${ }^{13} \mathrm{C} \mathrm{NMR}\left(\mathrm{CDCl}_{3}\right) \delta 139.2(\mathrm{~s}), 137.2(\mathrm{~d}), 133.9(\mathrm{~s}), 133.6$ (s), 132.4 (s), 131.9 (d, 2 C), 130.4 (d, 2 C), 128.8 (d, 2 C)128.7 (d, 2 C), 127.6 (d), 127.4 (d), 126.8 (d), 115.5 (d), 115.1 (d), 72.9 (d), $40.6(\mathrm{t})$; HRMS calcd for $\mathrm{C}_{22} \mathrm{H}_{19} \mathrm{OS}_{2} \mathrm{~F}\left(\mathrm{M}^{+}\right) 382.0861$, found 382 0850; HPLC (Chiracel OD, 2-propanol/hexane (10:90)) $t_{\mathrm{R}}$ $9.0 \mathrm{~min}$ ( $S$-isomer), $12.5 \mathrm{~min}$ ( $R$-isomer).

4,4-Bis(phenylthio)-1-(o-chlorophenyl)-3-butenol (1p): oil: ${ }^{13} \mathrm{C} \mathrm{NMR}\left(\mathrm{CDCl}_{3}\right) \delta 137.3(\mathrm{~d}), 131.9(\mathrm{~d}, 4 \mathrm{C}), 130.4(\mathrm{~d}, 2 \mathrm{C})$, 129.4 (s, 2 C), 128.8 (d, 2 C), 128.6 (d, 2 C), 127.5 (d, 2 C), $127.3(\mathrm{~s}), 127.1(\mathrm{~s}), 126.8$ (d, 2 C), $69.9(\mathrm{~d}), 38.8(\mathrm{t})$; HRMS calcd for $\mathrm{C}_{22} \mathrm{H}_{19} \mathrm{OS}_{2} \mathrm{Cl}\left(\mathrm{M}^{+}\right) 398.0565$, found 398.0567 ; HPLC (Chiracel OD, 2-propanol/hexane (5:95)) $t_{\mathrm{R}} 23.6 \mathrm{~min}$ (S-isomer), $26.1 \mathrm{~min}$ ( $R$-isomer).

4,4-Bis(phenylthio)-1-(m-chlorophenyl)-3-butenol (1q): oil; ${ }^{1} \mathrm{H}$ NMR $\left(\mathrm{CDCl}_{3}\right) \delta 7.32-7.05(14 \mathrm{H}, \mathrm{m}), 6.18(1 \mathrm{H}, \mathrm{t}, J=$ $7.2 \mathrm{~Hz}), 4.72(1 \mathrm{H}, \mathrm{t}, J=6.4 \mathrm{~Hz}), 2.86(2 \mathrm{H}, \mathrm{dd}, J=7.2,6.4$ $\mathrm{Hz}$ ); HRMS calcd for $\mathrm{C}_{22} \mathrm{H}_{19} \mathrm{OS} \mathrm{S}_{2} \mathrm{Cl}\left(\mathrm{M}^{+}\right) 398.0565$, found 398.0596; HPLC (Chiracel OD, 2-propanolhexane (10:90)) $t_{\mathrm{R}}$ $12.9 \mathrm{~min}$ ( $S$-isomer), $14.9 \mathrm{~min}$ ( $R$-isomer).

4,4-Bis (phenylthio)-1-( $m$-bromophenyl)-3-butenol (1r): oil; ${ }^{13} \mathrm{C} \mathrm{NMR}\left(\mathrm{CDCl}_{3}, 50 \mathrm{MHz}\right) \delta 145.8(\mathrm{~s}), 136.2$ (d), 135.7 (s), 133.5 (s), 132.9 (s), 132.1 (d, 2 C), 130.7 (d), 130.4 (d), 130.0 (d), 129.0 (d), 128.9 (d, 2 C), 128.8 (d), 128.7 (d, 2 C), 127.7 (d), 126.9 (d), 126.8 (d), 124.5 (d), 122.5 (s), 72.9 (d), 40.4 (t); HRMS calcd for $\mathrm{C}_{22} \mathrm{H}_{17} \mathrm{O}^{81} \mathrm{BrS}_{2}\left(\mathrm{M}^{+}\right) 441.9900$, found $441.9869 ; \mathrm{HPLC}$ (Chiracel OD, 2-propanol/hexane (5:95)) $t_{\mathrm{R}} 8.5 \mathrm{~min}$ ( $S$-isomer), $13.0 \mathrm{~min}(R$-isomer)

6,6-Bis (phenylthio)-2-methyl-1,5-hexadien-3-ol (1s): oil ${ }^{13} \mathrm{C} \mathrm{NMR}\left(\mathrm{CDCl}_{3}, 50 \mathrm{MHz}\right) \delta 146.6(\mathrm{~s}), 138.7$ (d), $135.7(\mathrm{~s}), 134.0$ (s), $131.7(\mathrm{~d}, 2 \mathrm{C}), 131.5(\mathrm{~s}), 130.4(\mathrm{~d}, 2 \mathrm{C}), 128.8(\mathrm{~d}, 2 \mathrm{C}), 128.7$ (d, 2 C), 127.4 (d), 126.8 (d), 111.4 (d), 74.8 (d), 36.8 (t), 17.9 (q): HRMS calcd for $\mathrm{C}_{19} \mathrm{H}_{20} \mathrm{OS}_{2}\left(\mathrm{M}^{+}\right) 328.0956$, found 328.0948 ; HPLC (Chiracel OD, 2-propanol/hexane (20:80)) $t_{\mathrm{R}} 8.5 \mathrm{~min}(S-$ isomer $), 13.0 \mathrm{~min}$ ( $R$-isomer).

5,5-Bis(phenylthio)-4-methyl-4-penten-2-ol (2a): oil; TLC (10\% EtOAc in hexane) $R_{f}=0.2 ;$ IR (neat) $3383 \mathrm{~cm}^{-1} ; \mathrm{MS} \mathrm{m} / z$ (rel intensity) $316\left(\mathrm{M}^{+}, 100\right), 297(10), 271(32), 206(28), 161$ (55), $97(68) ;{ }^{1} \mathrm{H} \mathrm{NMR}\left(\mathrm{CDCl}_{3}\right) \delta 7.25-7.10(10 \mathrm{H}, \mathrm{m}), 4.09(1$ $\mathrm{H}, \mathrm{m}), 2.93(1 \mathrm{H}, \mathrm{dd}, J=13.0,8.3 \mathrm{~Hz}), 2.68(1 \mathrm{H}, \mathrm{dd}, J=$ $13.0,5.0 \mathrm{~Hz}), 2.24(3 \mathrm{H}, \mathrm{s}), 1.27(2 \mathrm{H}, \mathrm{d}, J=6.2 \mathrm{~Hz}) ;{ }^{13} \mathrm{C} \mathrm{NMR}$ $\left(\mathrm{CDCl}_{3}\right) \delta 152.4(\mathrm{~s}), 135.4(\mathrm{~s}, 2 \mathrm{C}), 129.5(\mathrm{~s}, 2 \mathrm{C}), 128.5(\mathrm{~d}, 4$ C), $126.2(\mathrm{~s}), 126.0(\mathrm{~d}), 123.8(\mathrm{~s}), 67.3(\mathrm{~d}), 46.8(\mathrm{t}), 23.8(\mathrm{q})$, 22.9 (q); HRMS calcd for $\mathrm{C}_{18} \mathrm{H}_{20} \mathrm{OS}_{2}\left(\mathrm{M}^{+}\right) 316.0955$, found 316.0963 ; HPLC (Chiracel OD, 2-propanol/hexane (5:95)) $t_{\mathrm{R}} 6.5$ $\min (S$-isomer), $8.3 \mathrm{~min}$ ( $R$-isomer).

6,6-Bis(phenylthio)-5-methyl-5-hexen-3-ol (2b): oil; ${ }^{13} \mathrm{C}$ NMR $\left(\mathrm{CDCl}_{3}\right) \delta 153.0(\mathrm{~s}), 135.0$ (s, $2 \mathrm{C}$ ), 129.4 (d, 2 C), 129.2 (d, 2 C), 128.6 (d, 4 C), 126.3 (d), 126,1 (d), 123.3 (s), 72.5 (d), $44.9(\mathrm{t}), 30.9$ (t), 23.0 (q), 10.0 (q); HRMS calcd for $\mathrm{C}_{19} \mathrm{H}_{22} \mathrm{OS}_{2}$ $\left(\mathrm{M}^{+}\right) 330.1112$, found 330.1180 ; HPLC (Chiracel OD, 2-propanol/hexane (5:95)) $t_{\mathrm{R}} 9.1 \mathrm{~min}$ ( $\boldsymbol{S}$-isomer), $11.3 \mathrm{~min}$ ( $R$-isomer).

1,1-Bis(phenylthio)-2-methyl-1-hepten-4-ol (2c): oil; ${ }^{13} \mathrm{C}$ NMR $\left(\mathrm{CDCl}_{3}\right) \delta 153.0(\mathrm{~s}), 135.5(\mathrm{~s}, 2 \mathrm{C}), 129.4(\mathrm{~d}, 2 \mathrm{C}), 129.1$ (d, 2 C), 128.6 (d, 4 C), 126.2 (d), 126.0 (d), 123.7 (s), 70.9 (d), $45.3(\mathrm{t}), 40.2$ (t), 23.0 (q), 18.8 (q), 14.0 (q); HRMS calcd for $\mathrm{C}_{20} \mathrm{H}_{24} \mathrm{OS}_{2}\left(\mathrm{M}^{+}\right) 344.1268$, found 344.1263; HPLC (Chiracel OD, 2-propanol/hexane (10:90)) $t_{\mathrm{R}} 6.4 \mathrm{~min}(S$-isomer), $9.3 \mathrm{~min}$ ( $R$-isomer).

6,6-Bis (phenylthio)-2,5-dimethyl-5-hexen-3-ol (2d). Oil; ${ }^{13} \mathrm{C}$ NMR $\left(\mathrm{CDCl}_{3}\right) \delta 154.0(\mathrm{~s}), 135.5$ (s, $2 \mathrm{C}$ ), 130.1 (d, $2 \mathrm{C}$ ), 129.7 (d, 2 C), 129.3 (d, 4 C), 126.9 (d), 126.7 (d), 123.1 (s), 78.2 (d), 42.9 (t), 35.0 (d), 23.5 (q), 19.4 (q), 17.9 (q); HRMS calcd for $\mathrm{C}_{20} \mathrm{H}_{24} \mathrm{OS}_{2}\left(\mathrm{M}^{+}\right) 344.1265$, found 344.1263 ; HPLC (Chiracel OD, 2-propanol/hexane (3:97)) $t_{\mathrm{R}} 13.4 \mathrm{~min}$ ( $R$-isomer), $17.0 \mathrm{~min}$ ( $S$-isomer).

4,4-Bis(phenylthio)-3-methyl-1-phenyl-3-butenol (2e): oil; ${ }^{13} \mathrm{C} \mathrm{NMR}\left(\mathrm{CDCl}_{3}\right) \delta 151.8(\mathrm{~s}), 143.8(\mathrm{~s}), 135.5(\mathrm{~s}), 135.4(\mathrm{~s})$, 129.7 (d, 2 C), 129.1 (d, 2 C), 128.6(d, 6 C), 127.0 (d, 2 C), 126.3(d), 126.0 (d), 125.9 (d), 123.8 (s), 73.7 (d), 46.8 (t), 23.0 (q) HRMS calcd for $\mathrm{C}_{23} \mathrm{H}_{22} \mathrm{OS}_{2}\left(\mathrm{M}^{+}\right) 378.1112$, found 378.1086
HPLC (Chiracel OD, 2-propanol/hexane (10:90)) $t_{\mathrm{R}} 9.3 \mathrm{~min}(R$ isomer), $14.0 \mathrm{~min}$ ( $S$-isomer).

1,1-Bis(phenylthio)-2-methyl-1-octen-4-ol (2f): oil; ${ }^{13} \mathrm{C}$ NMR $\left(\mathrm{CDCl}_{3}\right) \delta 153.1$ (s), $135.6(\mathrm{~s}), 135.5(\mathrm{~s}), 129.5(\mathrm{~d}, 2 \mathrm{C})$, 129.1 (d, 2 C), 128.6 (d, 4 C), 126.2 (d), 126.0 (d), 123.7 (s), $71.1(\mathrm{~d}), 45.4(\mathrm{t}), 37.7(\mathrm{t}), 27.8(\mathrm{t}), 23.0(\mathrm{q}), 22.6(\mathrm{t}), 14.0(\mathrm{q})$ HRMS calcd for $\mathrm{C}_{21} \mathrm{H}_{26} \mathrm{OS}_{2}\left(\mathrm{M}^{+}\right) 358.1425$, found 358.1419 ; HPLC (Chiracel OD, 2-propanol/hexane (10:90)) $t_{\mathrm{R}} 5.7 \mathrm{~min}(S$ isomer), $7.5 \mathrm{~min}$ ( $R$-isomer).

1,1-Bis(phenylthio)-2-methyl-1-nonen-4-ol (2g). Oil; ${ }^{13} \mathrm{C}$ NMR $\left(\mathrm{CDCl}_{3}\right) \delta 153.0(\mathrm{~s}), 135.6(\mathrm{~s}, 2 \mathrm{C}), 129.4$ (d, $\left.2 \mathrm{C}\right), 128.6$ (d, 4 C), 126.2 (d), 126.0 (d), 123.6 (s), 71.1 (d), 45.4 (t), 38.0 (t), 31.7 (t), 25.3(t), 22.9(t), 22.5 (q), 14.0 (q); HRMS calcd for $\mathrm{C}_{22} \mathrm{H}_{28} \mathrm{OS}_{2}\left(\mathrm{M}^{+}\right) 372,1581$, found 372.1586 ; HPLC (Chiracel OD, 2-propanol/hexane (10:90)) $t_{\mathrm{R}} 4.7 \mathrm{~min}$ ( $S$-isomer), $6.4 \mathrm{~min}$ ( $R$-isomer).

1-(1,3-Dithianylidene)-2-methyl-3-pentanol (3a): HPLC (Chiracel OD, 2-propanol/hexane (1:99)) $t_{\mathrm{R}} 18.6 \mathrm{~min}(2 S, 3 R$ isomer), $20.8 \mathrm{~min}$ ( $2 R, 3 S$-isomer).

1-(1,3-Dithianylidene)-2-methyl-3-heptanol (3b): HPLC (Chiracel OD, 2-propanol/hexane (1:99)) $t_{\mathrm{R}} 13.1 \mathrm{~min}(2 S, 3 R$ isomer), $14.7 \mathrm{~min}$ ( $2 R, 3 S$-isomer).

1-(1,3-Dithianylidene)-2-methyl-3-octanol (3c): HPLC (Chiracel OD, 2-propanol/hexane (1:99)) $t_{\mathrm{R}} 12.8 \mathrm{~min}(2 S, 3 R$ isomer), $14.6 \mathrm{~min}$ ( $2 R, 3 S$-isomer).

1-(1,3-Dithianylidene)-2-methyl-3-nonanol (3d): HPLC (Chiracel OD, 2-propanol/hexane (1:99)) $t_{\mathrm{R}} 11.4 \mathrm{~min}(2 S, 3 R$ isomer), $13.3 \mathrm{~min}$ (2R,3S-isomer).

5,5-Bis (phenylthio)-4-penten-2-yl acetate (7a): oil; TLC (10\% EtOAc in hexane) $R_{f}=0.4$; IR (neat) $1731 \mathrm{~cm}^{-1} ; \mathrm{MS} \mathrm{m} / z$ (rel intensity) $345\left(\mathrm{M}^{+}+1,12\right), 344(1), 284(100), 207(50) ;{ }^{1} \mathrm{H}$ NMR $\left(\mathrm{CDCl}_{3}\right) \delta 7.33-7.16(10 \mathrm{H}, \mathrm{m}), 6.23(1 \mathrm{H}, \mathrm{t}, J=7.4 \mathrm{~Hz})$, $4.99(1 \mathrm{H}, \mathrm{m}), 2.71(2 \mathrm{H}, \mathrm{dd}, J=6.4,6.4 \mathrm{~Hz}), 2.01(3 \mathrm{H}, \mathrm{s})$, $1.24(3 \mathrm{H}, \mathrm{d}, J=6.3 \mathrm{~Hz}) ;{ }^{13} \mathrm{C} \mathrm{NMR}\left(\mathrm{CDCl}_{3}\right) \delta 170.4(\mathrm{~s}), 137.0$, $133.9,133.7,132.5,132.0,130.5$ (d, 2 C), 128.9 (d, 2 C), 128.7 (d, 2 C), 127.5 (d), 126.9 (d), 125.8,69.8 (d), 37.3 (t), 21.2 (q), 19.7 (q); HRMS calcd for $\mathrm{C}_{19} \mathrm{H}_{20} \mathrm{O}_{2} \mathrm{~S}_{2}\left(\mathrm{M}^{+}\right) 344.0904$, found 344.0909 .

6,6-Bis(phenylthio)-5-hexen-3-yl acetate (7b): oil; IR (neat) $1724 \mathrm{~cm}^{-1} ;{ }^{13} \mathrm{C} \mathrm{NMR}\left(\mathrm{CDCl}_{3}\right) \delta 170.6(\mathrm{~s}), 137.2$ (d), 133.9 (s), $133.7(\mathrm{~s}), 132.2(\mathrm{~s}), 131.9(\mathrm{~d}, 2 \mathrm{C}), 130.5$ (d, $2 \mathrm{C}), 128.8(\mathrm{~d}$, 2 C), 128.6 (d, 2 C), 127.6 (d), 126.8 (d), 74.3 (d), 35.2 (t), 26.8 (t), 21.2 (q), 9.6 (q); HRMS calcd for $\mathrm{C}_{20} \mathrm{H}_{22} \mathrm{O}_{2} \mathrm{~S}_{2}\left(\mathrm{M}^{+}\right)$358.1061, found 358.1034

1,1-Bis(phenylthio)-1-hepten-4-yl acetate (7c): oil; IR (neat) $1730 \mathrm{~cm}^{-1} ;{ }^{13} \mathrm{C} \mathrm{NMR}\left(\mathrm{CDCl}_{3}, 50 \mathrm{MHz}\right) \delta 170.6(\mathrm{~s}), 137.3$ (d), 133.9 (s), 133.1 (s), $132.3(\mathrm{~s}), 132.0(\mathrm{~d}, 2 \mathrm{C}), 130.5$ (d, $2 \mathrm{C}$ ), 128.8 (d, 2 C), 128.7 (d, 2 C), 127.6 (d), 126.9 (d), 72.9 (d), 36.0 (t), 35.7 d), 21.2 (q), 18.5 (q), 13.9 (q); HRMS calcd for $\mathrm{C}_{21} \mathrm{H}_{24} \mathrm{O}_{2} \mathrm{~S}_{2}\left(\mathrm{M}^{+}\right) 372.1217$, found 372.1225

6,6-Bis(phenylthio)-2-methyl-5-hexen-3-yl acetate (7d): oil; ${ }^{13} \mathrm{C} \mathrm{NMR}\left(\mathrm{CDCl}_{3}\right) \delta 170.6$ (s), 137.7 (d), 134.0 (s, 2 C), 133.8 (s), 132.1 (d, 2 C), 130.5 (d, 2 C), 128.9 (d, 2 C), 128.7 (d, 2 C), 127.6 (d), 126.9 (d), 76.5 (d), $33.2(\mathrm{t}), 31.5$ (d), 21.1 (q), 18.7 (q), $17.8(q)$; HRMS calcd for $\mathrm{C}_{21} \mathrm{H}_{24} \mathrm{O}_{2} \mathrm{~S}_{2}\left(\mathrm{M}^{+}\right) 372.1217$, found 372.1198

4,4-Bis(phenylthio)-1.phenyl-3-butenyl acetate (7e): oil; IR (neat) $1724 \mathrm{~cm}^{-1} ;{ }^{13} \mathrm{C}$ NMR $\left(\mathrm{CDCl}_{3}\right) \delta 169.8(\mathrm{~s}), 139.4$ (s), 135.9 (d), 133.7 (s), 133.4 (s), 132.9 (s), 132.0 (d, 2 C), 130.4 (d, 2 C), 128.7 (d, 2 C), 128.6 (d, 2 C), $128.4(\mathrm{~d}, 2 \mathrm{C}), 128.0$ (d, 2 C), 127.5 (d), 126.8 (d), 126.3 (d, 2 C), 74.5 (d), 37.7 (t), 21.0 (q); $\mathrm{HRMS}$ calcd for $\mathrm{C}_{24} \mathrm{H}_{22} \mathrm{O}_{2} \mathrm{~S}_{2}\left(\mathrm{M}^{+}\right)$406.1061, found 406.1069 .

4,4-Bis(phenylthio)-1-(o-methylphenyl)-3-butenyl acetate (7f): oil; IR (neat) $1727 \mathrm{~cm}^{-1} ;{ }^{13} \mathrm{C} \mathrm{NMR}\left(\mathrm{CDCl}_{3}\right) \delta 169.9$ (s), 138.0 (s), 135.9 (d), 133.8 (s), $133.8(\mathrm{~s}), 133.4(\mathrm{~s}), 133.0(\mathrm{~s})$, $132.2(\mathrm{~d}, 2 \mathrm{C}), 130.4$ (d, 2 C), 128.8 (d, 2 C), 128.7 (d, 2 C), 127.8 (d) 127.7 (d), 126.8 (d), 126.1 (d), 125.8 (d), 71.6 (d), 37.0 (t), 21.1 (q), 19.1 (q); HRMS calcd for $\mathrm{C}_{25} \mathrm{H}_{24} \mathrm{O}_{2} \mathrm{~S}_{2}\left(\mathrm{M}^{+}\right)$ 420.1217 , found 420.1216 .

4,4-Bis(phenylthio)-1-(m-methylphenyl)-3-butenyl acetate (7g): oil; IR (neat) $1733 \mathrm{~cm}^{-1} ;{ }^{13} \mathrm{C}$ NMR (CDCls) $\delta 169.7$ (s), 139.3 (s), 137.9 (s), 136.2 (d), 133.7 (s), $133.4(\mathrm{~s}), 132.6(\mathrm{~s})$, 131.8 (d, 2 C), 130.3 (d, 2 C), 128.7 (d, 3 C), 128.5 (d, 2 C), 128.2 (d), 127.4 (d), 126.9 (d), 123.3 (d), 74.5 (d), 37.7 (t), 21.3 (q), 21.0 (q); HRMS calcd for $\mathrm{C}_{25} \mathrm{H}_{24} \mathrm{O}_{2} \mathrm{~S}_{2}\left(\mathrm{M}^{+}\right) 420.1217$, found 420.1216 . 
4,4-Bis(phenylthio)-1-(p-methylphenyl)-3-butenyl acetate (7h): oil; IR(neat) $1729 \mathrm{~cm}^{-1} ;{ }^{13} \mathrm{C} \mathrm{NMR}\left(\mathrm{CDCl}_{3}\right) \delta 170.0$ (s), 137.7 (s), 136.5 (s), 136.4 (d), 133.8 (s), 133.5 (s), 132.7 (s), 131.9 (d, 2 C), 130.5 (d, 2 C), 129.1 (d, 2 C), 128.8 (d, 2 C), 128.6 (d, 2 C), 127.5 (d), 126.8 (d), 126.4 (d, 2 C), 74.5 (d), 37.7 (t), 21.1 (q); HRMS calcd for $\mathrm{C}_{25} \mathrm{H}_{24} \mathrm{O}_{2} \mathrm{~S}_{2}\left(\mathrm{M}^{+}\right)$420.1217, found 420.1216 .

4,4-Bis(phenylthio)-1-( $p$-(methylethyl)phenyl)-3-butenyl acetate (7i): oil; IR (neat) $1734 \mathrm{~cm}^{-1} ;{ }^{13} \mathrm{C} \mathrm{NMR}\left(\mathrm{CDCl}_{3}\right)$ $\delta 170.0(\mathrm{~s}), 148.7(\mathrm{~s}) .136 .9(\mathrm{~s}), 136.2(\mathrm{~d}), 133.8(\mathrm{~s}), 133.5(\mathrm{~s})$, 132.8 (s), 132.0 (d, 2 C), 130.5 (d, 2 C), 128.8 (d, 2 C), 127.6 (d), 126.9 (d), 126.5 (d, 4 C), 74.6 (d), 37.8 (t), 33.7 (d), 23.9 (q, $2 \mathrm{C}$ ), 21.2 (q); HRMS calcd for $\mathrm{C}_{27} \mathrm{H}_{28} \mathrm{O}_{2} \mathrm{~S}_{2}\left(\mathrm{M}^{+}\right) 448.1530$, found 448.1523; HPLC (Chiracel OD, 2-propanol/hexane (20:80)) $t_{\mathrm{R}}$ $4.7 \mathrm{~min}$ ( $S$-isomer), $5.2 \mathrm{~min}(R$-isomer).

4,4-Bis(phenylthio)-1-(o-methoxyphenyl)-3-butenyl acetate (7j): oil; IR (neat) $1737 \mathrm{~cm}^{-1} ;{ }^{13} \mathrm{C} \mathrm{NMR}\left(\mathrm{CDCl}_{3}\right) \delta 169.6$ (s), 155.8 (s), 137.6(d), 134.0 (s), 133.7 (s), 131.9 (s), 131.6 (d, 2 C), 130.2 (d, 2 C), 128.6 (d, 3 C), 128.5 (d, 2 C), 127.9 (d), 127.2 (d), 126.6 (d), 126.1 (d), 120.3 (d), 120.3 (d), 110.4 (d), 69.3 (d), 55.2 (q), 36.5 (t), 21.0 (q); HRMS calcd for $\mathrm{C}_{25} \mathrm{H}_{24} \mathrm{O}_{3} \mathrm{~S}_{2}$ $\left(\mathrm{M}^{+}\right)$436.1167, found 436.1165; HPLC (Chiracel OD, 2-propanol/hexane (5:95)) $t_{\mathrm{R}} 5.8 \mathrm{~min}$ ( $S$-isomer), $7.9 \mathrm{~min}$ ( $R$-isomer).

4,4-Bis(phenylthio)-1-(m-methoxyphenyl)-3-butenyl acetate (7k): oil; IR (neat) $1732 \mathrm{~cm}^{-1} ;{ }^{13} \mathrm{C} \mathrm{NMR}\left(\mathrm{CDCl}_{3}\right) \delta 169.9$ (s), 156.0 (s), 137.8 (d), 134.1 (s), 133.9 (s), 132.0 (s), 131.8 (d, 2 C), 130.4 (d, 2 C), 128.7 (d, 2 C), 128.6 (d, 2 C), 128.1 (s), 127.4 (d), 127.3 (d), 126.7 (d), 126.3 (d), 120.5 (d), 110.5 (d), 69.5(d), 55.4 (q), 36.6 (t), 21.2 (q); HRMS calcd for $\mathrm{C}_{25} \mathrm{H}_{24} \mathrm{O}_{3} \mathrm{~S}_{2}$ $\left(\mathrm{M}^{+}\right)$436.1167, found 436.1160 .

4,4-Bis(phenylthio)-1-(m-(trifluoromethyl)phenyl)-3butenyl acetate (71): oil; IR (neat) $1730 \mathrm{~cm}^{-1} ;{ }^{13} \mathrm{C}$ NMR $\left(\mathrm{CDCl}_{3}\right) \delta 169.8$ (s), 141.1 (d), 134.4, 133.8, 132.3, 130.4, 130.0, $129.8,129.2,129.1,128.9,128.7,128.5,128.2,127.8,126.9$, $126.5,124.6,73.9$ (d), 37.6 (t), 21.0 (q); HRMS calcd for $\mathrm{C}_{24} \mathrm{H}_{21} \mathrm{~F}_{3} \mathrm{O}_{2} \mathrm{~S}_{2}\left(\mathrm{M}^{+}\right)$474.0935, found 474.0934; HPLC (Chiracel OD, 2-propanol/hexane (10:90)) $t_{\mathrm{R}} 3.6 \mathrm{~min}$ ( $S$-isomer), $3.8 \mathrm{~min}$ $(R$-isomer).

4,4-Bis (phenylthio)-1-(p-(trifluoromethyl)phenyl)-3butenyl acetate $(7 \mathrm{~m})$ : oil; IR (neat) $1733 \mathrm{~cm}^{-1}$; ${ }^{13} \mathrm{C}$ NMR $\left(\mathrm{CDCl}_{3}\right) \delta 169.9$ (s), 143.6 (s), 134.1 (d), 134.0 (s), 133.5 (s), 133.1 (s), 132.4 (d, 2 C), 130.5 (d, 2 C), 129.9 (s), 128.9 (d, 2 C), 128.7 (d, 2 C), 127.9 (d), 127.0 (d), 126.7 (d), 125.5 (d, 2 C), $125.4(\mathrm{~d}), 74.0(\mathrm{~d}), 37.6(\mathrm{t}), 21.0(\mathrm{q})$; HRMS calcd for $\mathrm{C}_{25} \mathrm{H}_{21} \mathrm{O}_{2} \mathrm{~S}_{2} \mathrm{~F}_{3}\left(\mathrm{M}^{+}\right)$474.0935, found 474.0934.

4,4-Bis(phenylthio)-1-(m-fluorophenyl)-3-butenyl acetate (7n): oil; IR (neat) $1731 \mathrm{~cm}^{-1} ; \mathrm{MS} \mathrm{m} / \boldsymbol{z}$ (rel intensity) $424\left(\mathrm{M}^{+}, 8\right), 365(50), 257(100) ;{ }^{1} \mathrm{H}$ NMR $\left(\mathrm{CDCl}_{3}\right) \delta 7.30-7.05$ $(14 \mathrm{H}, \mathrm{m}), 6.04(1 \mathrm{H}, \mathrm{t}, J=7.4 \mathrm{~Hz}), 5.79(1 \mathrm{H}, \mathrm{t}, J=6.3 \mathrm{~Hz})$, $2.99(2 \mathrm{H}, \mathrm{dd}, J=7.4,6.3 \mathrm{~Hz}), 2.09(3 \mathrm{H}, \mathrm{s})$; HRMS calcd for $\mathrm{C}_{24} \mathrm{H}_{21} \mathrm{O}_{2} \mathrm{~S}_{2} \mathrm{~F}\left(\mathrm{M}^{+}\right) 424.0967$, found 424.0972; HPLC (Chiracel OD , 2-propanol/hexane (5:95)) $t_{\mathrm{R}} 9.1 \mathrm{~min}(S$-isomer $), 10.7 \mathrm{~min}$ $(R$-isomer).

4,4-Bis(phenylthio)-1-(p-fluorophenyl)-3-butenyl acetate (7o): oil; IR (neat) $1731 \mathrm{~cm}^{-1} ;{ }^{13} \mathrm{C} \mathrm{NMR}\left(\mathrm{CDCl}_{3}\right) \delta 169.9$ (s) $164.0,160.8,135.4$ (s), 135.3 (d), 133.7 (s), 133.4 (s), 132.2 (d, 2 C), 130.5 (d), 130.4 (d, 2 C), 128.8 (d, 2 C), 128.7 (d, 2 C), 128.3 (d), 128.2 (d), 127.5 (d), 126.9 (d), 115.5 (d), 115.2 (d) 74.0 (d), 37.7 (t), 21.1 (q); HRMS calcd for $\mathrm{C}_{18} \mathrm{H}_{20} \mathrm{OS}_{2}\left(\mathrm{M}^{+}\right)$ 424.0967, found 424.0973; HPLC (Chiracel OD, 2-propanol hexane $(3: 97)) t_{\mathrm{R}} 8.8 \mathrm{~min}$ ( $S$-isomer), $10.2 \mathrm{~min}$ ( $R$-isomer).

4,4-Bis(phenylthio)-1-(o-chlorophenyl)-3-butenyl acetate (7p): oil; IR (neat) $1738 \mathrm{~cm}^{-1} ;{ }^{13} \mathrm{C} \mathrm{NMR}\left(\mathrm{CDCl}_{3}\right) \delta 169.5$ (s), $137.4(\mathrm{~s}), 135.2(\mathrm{~d}), 133.7(\mathrm{~s}), 133.4(\mathrm{~s}), 133.3$ (d), 132.2 (d), 132.0 (s), 130.4 (d, 2 C), 129.5 (d), 128.9 (d), 128.8 (d, 2 C), 128.6 (d, 2 C), 127.6 (d) 127.1 (d), 126.9 (d), 126.8 (d), 71.3 (d), 36.4 (t), 21.0 (q); HRMS calcd for $\mathrm{C}_{24} \mathrm{H}_{21} \mathrm{O}_{2} \mathrm{~S}_{2} \mathrm{Cl}\left(\mathrm{M}^{+}\right)$ 440.0671, found 440.0663; HPLC (Chiracel OD, 2-propanol hexane $(10: 90)) t_{\mathrm{R}} 3.6 \mathrm{~min}$ ( $S$-isomer), $3.8 \mathrm{~min}$ ( $R$-isomer).

4,4-Bis (phenylthio)-1-( $m$-chlorophenyl)-3-butenyl acetate (7q): oil; IR (neat) $1736 \mathrm{~cm}^{-1} ;{ }^{13} \mathrm{C} \mathrm{NMR}\left(\mathrm{CDCl}_{3}, 50 \mathrm{MHz}\right.$ ) $\delta 169.7(\mathrm{~s}), 141.6(\mathrm{~s}), 134.4(\mathrm{~d}), 134.3(\mathrm{~s}), 133.7(\mathrm{~s}), 133.6(\mathrm{~s})$, 133.1 (s), 132.3 (d, 2 C), 130.4 (d,2 C), 129.7 (d), 128.8 (d, 2 C), 128.6 (d, 2 C), 128.1 (d), 127.7 (d), 126.9 (d), 126.4 (d), 124.5 (d), 73.8 (d), 37.5 (d), 20.9 (q); HRMS calcd for $\mathrm{C}_{24} \mathrm{H}_{21} \mathrm{O}_{2} \mathrm{~S}_{2} \mathrm{Cl}$
( $\left.\mathrm{M}^{+}\right)$440.0671, found 440.0683; HPLC (Chiracel OD, 2-propanol/hexane (5:95)) $t_{\mathrm{R}} 7.1 \mathrm{~min}(S$-isomer), $7.7 \mathrm{~min}$ ( $R$-isomer).

4,4-Bis(phenylthio)-1-(m-bromophenyl)-3-butenyl acetate (7r): oil; ${ }^{13} \mathrm{C} \mathrm{NMR}\left(\mathrm{CDCl}_{3}\right) \delta 169.7(\mathrm{~s}), 141.9(\mathrm{~s}), 134.3$ (d), 133.7 (s), 133.6 (s), $133.1(\mathrm{~s}), 132.3(\mathrm{~d}), 131.1$ (d, 2 C), 130.4 (d, 2 C), 130.0 (d), 129.3 (d), 128.9 (d, 2 C), 128.7 (d, 2 C), 127.8 (d), 126.9 (d), 125.0 (d), 122.5 (s), 73.8 (d), 37.6 (t), 21.0 (q); HRMS calcd for $\mathrm{C}_{24} \mathrm{H}_{21} \mathrm{O}_{2}{ }^{79} \mathrm{BrS}_{2}\left(\mathrm{M}^{+}\right) 484.0166$, found 484.0151 ; HPLC (Chiracel OD, 2-propanolhexane (5:95)) $t_{\mathrm{R}} 8.1 \mathrm{~min}(S-$ isomer), $8.9 \mathrm{~min}$ ( $R$-isomer).

6,6-Bis(phenylthio)-2-methyl-1,5-hexadien-3-yl acetate (7s): oil; IR (neat) $1734 \mathrm{~cm}^{-1} ;{ }^{13} \mathrm{C} \mathrm{NMR}\left(\mathrm{CDCl}_{3}\right) \delta 169.9$ (s), 142.3 (s), 136.6 (d), 133.9 (s), $133.6(\mathrm{~s}), 132.4(\mathrm{~s}), 132.0$ (d, 2 C), $128.8(\mathrm{~d}, 2 \mathrm{C}), 128.6(\mathrm{~d}, 2 \mathrm{C}), 127.5(\mathrm{~d}), 126.8(\mathrm{~d}), 112.9(\mathrm{t})$, 75.7 (d), 34.3 (t), 21.0 (q), 18.4 (q); HRMS calcd for $\mathrm{C}_{21} \mathrm{H}_{22} \mathrm{O}_{2} \mathrm{~S}_{2}$ $\left(\mathrm{M}^{+}\right) 370.1061$, found 370.1025 .

5,5-Bis(phenylthio)-4-methyl-4-penten-2-yl acetate (8a): oil; TLC (5\% EtOAc in hexane) $R_{f}=0.30$; IR (neat) $1730 \mathrm{~cm}^{-1}$; MS $m / z$ (rel intensity) $358\left(\mathrm{M}^{+}, 25\right), 298(65), 221(100) ;{ }^{1} \mathrm{H}$ NMR $\left(\mathrm{CDCl}_{3}\right) \delta 7.24-7.05(10 \mathrm{H}, \mathrm{m}), 5.23(1 \mathrm{H}, \mathrm{m}), 3.08(1 \mathrm{H}$, dd, $J=13.2,8.7 \mathrm{~Hz}), 2.74(1 \mathrm{H}, \mathrm{dd}, J=13.2,4.7 \mathrm{~Hz}), 2.20(3$ $\mathrm{H}, \mathrm{s}), 2.00(3 \mathrm{H}, \mathrm{s}), 1.29(3 \mathrm{H}, \mathrm{d}, J=6.2 \mathrm{~Hz}) ;{ }^{13} \mathrm{C} \mathrm{NMR}\left(\mathrm{CDCl}_{3}\right)$ $\delta 170.3(\mathrm{~s}), 150.3(\mathrm{~s}), 135.2(\mathrm{~s}, 2 \mathrm{C}), 129.7(\mathrm{~d}, 2 \mathrm{C}), 129.6(\mathrm{~d}, 2$ C), $128.4(\mathrm{~d}, 4 \mathrm{C}), 126.3(\mathrm{~d}), 126.2(\mathrm{~d}), 125.2(\mathrm{~s}), 69.3(\mathrm{~d}), 44.0$ (t), 22.5 (q), 21.2 (q), 20.2 (q); HRMS calcd for $\mathrm{C}_{20} \mathrm{H}_{22} \mathrm{O}_{2} \mathrm{~S}_{2}\left(\mathrm{M}^{+}\right)$ 358.1061 , found 358.1041 .

6,6-Bis(phenylthio)-5-methyl-5-hexen-3-yl acetate $(8 \mathrm{~b})$ oil; IR (neat) $1731 \mathrm{~cm}^{-1} ;{ }^{13} \mathrm{C} \mathrm{NMR}\left(\mathrm{CDCl}_{3}\right) \delta 170.4(\mathrm{~s}), 150.4$ (s), 135.3 (s, 2 C), 129.8 (d, 4 C), 128.5 (d, 4 C), 126.3 (d, 2 C), $125.2(\mathrm{~s}), 73.7(\mathrm{~d}), 41.7(\mathrm{t}), 27.5(\mathrm{t}), 22.6(\mathrm{q}), 21.1(\mathrm{q}), 9.6(\mathrm{q})$ HRMS calcd for $\mathrm{C}_{21} \mathrm{H}_{24} \mathrm{O}_{2} \mathrm{~S}_{2}\left(\mathrm{M}^{+}\right) 372.1217$, found 372.1204 .

1,1-Bis(phenylthio)-2-methyl-1-hepten-4-yl acetate (8c): oil; IR (neat) $1732 \mathrm{~cm}^{-1}$; ${ }^{13} \mathrm{C} \mathrm{NMR}\left(\mathrm{CDCl}_{3}\right) \delta 170.5$ (s), 150.6 (s), 135.4 (s, 2 C), 129.9 (d, 2 C), 129.8 (d, 2 C), 128.5 (d, 4 C), 126.3 (d, 2 C), 125.2 (s), 72.4 (d), 42.2 (d), 36.8 (t), 22.7 (q), $21.2(\mathrm{q}), 18.6(\mathrm{t}), 13.8(\mathrm{q})$; HRMS calcd for $\mathrm{C}_{22} \mathrm{H}_{26} \mathrm{O}_{2} \mathrm{~S}_{2}\left(\mathrm{M}^{+}\right)$ 386.1374 , found 386.1374 .

6,6-Bis(phenylthio)-2,5-dimethyl-5-hexen-3-yl acetate (8d): oil; IR (neat) $1726 \mathrm{~cm}^{-1} ;{ }^{13} \mathrm{C} \mathrm{NMR}\left(\mathrm{CDCl}_{3}\right) \delta 170.3$ (s), $150.6(\mathrm{~s}), 135.3(\mathrm{~s}), 135.2(\mathrm{~s}), 129.9$ (d, 2 C), 129.7 (d, 2 C), 128.4 (d, 4 C), 126.2 (d), 126.17 (d), $125.0(\mathrm{~s}), 76.5(\mathrm{~d}), 39.2(\mathrm{t})$, 32.2 (d), 22.6 (q), 21.0 (q), 18.3 (q), 17.6 (q); HRMS calcd for $\mathrm{C}_{23} \mathrm{H}_{24} \mathrm{OS}_{2}\left(\mathrm{M}^{+}\right) 386.1374$, found 386.1376 .

4,4-Bis(phenylthio)-3-methyl-1-phenyl-3-butenyl acetate (8e): oil; IR (neat) $1736 \mathrm{~cm}^{-1} ;{ }^{13} \mathrm{C} \mathrm{NMR}\left(\mathrm{CDCl}_{3}\right) \delta 170.0$ $(\mathrm{s}), 149.5(\mathrm{~s}), 139.7(\mathrm{~s}), 135.3(\mathrm{~s}), 135.2(\mathrm{~s}), 130.0(\mathrm{~d}, 2 \mathrm{C}), 129.5$ (d, 2 C), 128.5 (d, 4 C), 128.1 (d), 126.6 (d, 2 C), 126.4 (d), 126.2 (d), 126.0 (s), 74.5 (d), 44.0 (t), 22.6 (q), 21.2 (q); HRMS calcd for $\mathrm{C}_{25} \mathrm{H}_{24} \mathrm{O}_{2} \mathrm{~S}_{2}\left(\mathrm{M}^{+}\right)$420.1218, found 420.1224 .

1,1-Bis(phenylthio)-2-methyl-1-octen-4-yl acetate (8f): oil; IR (neat) $1733 \mathrm{~cm}^{-1} ;{ }^{13} \mathrm{C} \mathrm{NMR}\left(\mathrm{CDCl}_{3}\right) \delta 170.3$ (s), 150.4 (s), 135.3 (s), 135.2 (s), 129.7 (d, 2 C), 129.68 (d, 2 C), 128.4 (d, 4 C), $126.2(\mathrm{~d}, 2 \mathrm{C}), 125.2(\mathrm{~s}), 72.5(\mathrm{~d}), 42.0(\mathrm{t}), 34.3(\mathrm{t}), 27.3$ $(\mathrm{t}), 22.5(\mathrm{q}), 22.3(\mathrm{t}), 21.1(\mathrm{q}), 13.8(\mathrm{q})$; HRMS calcd for $\mathrm{C}_{23} \mathrm{H}_{28} \mathrm{O}_{2} \mathrm{~S}_{2}\left(\mathrm{M}^{+}\right) 440.1530$, found 400.1536 .

1,1-Bis(phenylthio)-2-methyl-1-nonen-4-yl acetate (8g): oil; IR (neat) $1731 \mathrm{~cm}^{-1} ;{ }^{13} \mathrm{C}$ NMR $\left(\mathrm{CDCl}_{3}\right) \delta 170.6$ (s), 150.7 (s), 135.5 (s), 134.4 (s), 129.9 (d, 2 C), 129.8 (d, 2 C), 128.6 (d, 4 C) $126.4(\mathrm{~d}, 2 \mathrm{C}), 125.6(\mathrm{~s}), 72.8(\mathrm{~d}), 42.2(\mathrm{t}), 34.7(\mathrm{t}), 31.6$ $(\mathrm{t}), 25.0(\mathrm{t}), 22.7(\mathrm{q}), 22.5(\mathrm{t}), 21.3(\mathrm{q}), 14.0(\mathrm{q})$; HRMS calcd for $\mathrm{C}_{24} \mathrm{H}_{30} \mathrm{O}_{2} \mathrm{~S}_{2}\left(\mathrm{M}^{+}\right)$414.1687, found 414.1677.

1-(1,3-Dithianylidene)-2-methyl-3-pentyl acetate $(9 a)$ : oil: TLC ( $5 \%$ EtOAc in hexane) $R_{f}=0.3$; IR (neat) $1731 \mathrm{~cm}^{-1}$; MS $m / z$ (rel intensity) $261\left(\mathrm{M}^{+}+1,18\right), 260(1), 200(30), 159$ (100); ${ }^{1} \mathrm{H}$ NMR $\left(\mathrm{CDCl}_{3}\right) \delta 5.75(1 \mathrm{H}, \mathrm{d}, J=9.8 \mathrm{~Hz}), 4.69(1 \mathrm{H}$, $\mathrm{m}), 2.87(1 \mathrm{H}, \mathrm{m}), 2.84-2.74(4 \mathrm{H}, \mathrm{m}), 2.13-2.04(2 \mathrm{H}, \mathrm{m})$, $1.98(3 \mathrm{H}, \mathrm{s}), 1.47(2 \mathrm{H}, \mathrm{m}), 0.91(3 \mathrm{H}, \mathrm{d}, J=4.2 \mathrm{~Hz}), 0.78(3$ $\mathrm{H}, \mathrm{t}, J=5.0 \mathrm{~Hz}) ;{ }^{13} \mathrm{C} \mathrm{NMR}\left(\mathrm{CDCl}_{3}\right) \delta 170.7(\mathrm{~s}), 134.5(\mathrm{~d}), 127.3$ $(\mathrm{s}), 78.1(\mathrm{~s}), 37.3(\mathrm{t}), 30.2(\mathrm{t}), 29.6(\mathrm{t}), 25.2(\mathrm{t}), 25.1(\mathrm{t}), 20.9(\mathrm{q})$, 16.7 (q), 9.8 (q); HRMS calcd for $\mathrm{C}_{13} \mathrm{H}_{22} \mathrm{O}_{2} \mathrm{~S}_{2}\left(\mathrm{M}^{+}\right)$260.0904, found 260.0912 .

1-(1,3-Dithianylidene)-2-methyl-3-heptyl acetate (9b) oil; IR (neat) $1730 \mathrm{~cm}^{-1} ;{ }^{13} \mathrm{C} \mathrm{NMR}\left(\mathrm{CDCl}_{3}\right) \delta 170.8$ (s), 134.7 (d) $127.3(\mathrm{~s}), 76.8(\mathrm{~d}), 37.3(\mathrm{~d}), 31.9(\mathrm{t}), 30.3(\mathrm{t}), 29.7(\mathrm{t}), 27.6$ (t), 25.1 (t), 22.5 (t), 21.0 (q), 16.7 (q), 13.9 (q); HRMS calcd for $\mathrm{C}_{14} \mathrm{H}_{24} \mathrm{O}_{2} \mathrm{~S}_{2}\left(\mathrm{M}^{+}\right) 288.1217$, found 288.1216 . 
1-(1,3-Dithianylidene)-2-methyl-3-octyl acetate (9c); oil; IR (neat) $1731 \mathrm{~cm}^{-1} ;{ }^{13} \mathrm{C} \mathrm{NMR}\left(\mathrm{CDCl}_{3}\right) \delta 170.6$ (s), 134.5 (d), $127.2(\mathrm{~s}), 76.7(\mathrm{~d}), 37.6(\mathrm{~d}), 32.1(\mathrm{t}), 31.5(\mathrm{t}), 30.2(\mathrm{t}), 29.6(\mathrm{t})$, $25.0(\mathrm{t}), 24.9(\mathrm{t}), 22.3(\mathrm{t}), 20.9(\mathrm{q}), 16.7(\mathrm{q}), 13.8(\mathrm{q}) ;$ HRMS calcd for $\mathrm{C}_{15} \mathrm{H}_{26} \mathrm{O}_{2} \mathrm{~S}_{2}\left(\mathrm{M}^{+}\right) 302.1374$, found 302.1348 .

1-(1,3-Dithianylidene)-2-methyl-3-nonyl acetate (9d): oil; IR (neat) $1731 \mathrm{~cm}^{-1} ;{ }^{13} \mathrm{C} \mathrm{NMR}\left(\mathrm{CDCl}_{3}, 50 \mathrm{MHz}\right) \delta 170.6$ (s), $134.6(\mathrm{~d}), 127.2(\mathrm{~s}), 76.9(\mathrm{~d}), 37.6(\mathrm{~d}), 32.2(\mathrm{t}), 31.6(\mathrm{t}), 30.2$ $(\mathrm{t}), 29.6(\mathrm{t}), 29.0(\mathrm{t}), 25.3(\mathrm{t}), 25.0(\mathrm{t}), 22.4(\mathrm{t}), 20.9(\mathrm{q}), 16.7(\mathrm{q})$ 14.0 (q); HRMS calcd for $\mathrm{C}_{16} \mathrm{H}_{28} \mathrm{O}_{2} \mathrm{~S}_{2}\left(\mathrm{M}^{+}\right) 316.1530$, found 316.1530 .

(S)-4-Hydroxy-2-heptanone (10). A cold $\left(-78^{\circ} \mathrm{C}\right)$ solution of $(S)-2 \mathrm{c}(0.18 \mathrm{~g}, 0.47 \mathrm{mmol}, 86 \%$ ee $)$ in $\mathrm{CH}_{2} \mathrm{Cl}_{2}(30 \mathrm{~mL})$ was treated with ozone. The reaction was monitored by TLC analysis. After complete consumption of $(S)-8 \mathrm{c}, \mathrm{Me}_{2} \mathrm{~S}(0.5 \mathrm{~mL})$ was added. The mixture was warmed to room temperature and stirring maintained for $4 \mathrm{~h}$. The mixture was concentrated and separated by silica gel chromatography and HPLC (EtOAc/hexane $(1: 1)$ ) to give $(S)-10(20 \mathrm{mg}, 38 \%),[\alpha]^{25}{ }_{\mathrm{D}}+44^{\circ}$ $\left(c=0.18, \mathrm{CHCl}_{3}\right)\left(\right.$ lit. $^{7}[\alpha]_{\mathrm{D}}+35.1^{\circ}\left(c=2.1, \mathrm{CHCl}_{3}, 58 \%\right.$ ee $)$. Two isomers of 3-hydroxy-3-methyl-5-propyl-2,3,4,5-tetrahydrofuran-2-one $(37 \%, 55: 45)$ were also isolated as side products.

5-Phenyl-2,3,4,5-tetrahydrofuran-2-one (11e). The alcohol 1e (60 mg, 91\% ee favoring $(R)$-configuration), obtained from lipase-catalyzed hydrolysis of acetate $7 e$ (entry 6 of Table 2), was treated with $\mathrm{HgCl}_{2}$ by a procedure silimar to that for hop lactone to give $(+)-11 \mathrm{e}(24 \mathrm{mg}, 90 \%)$ in favor of the $(R)$ configuration $(91 \%$ ee $),[\alpha]^{25} \mathrm{D}+18^{\circ}\left(c=1.1, \mathrm{CHCl}_{3}\right)\left(\right.$ lit. $^{8}[\alpha]_{\mathrm{D}}$ $+32.5^{\circ}(c=1, \mathrm{MeOH})$ ).

5-(Methylethenyl)-2,3,4,5-tetrahydrofuran-2-one (Hop Lactone) (11s). (S)-Alcohol 1s $(0.44 \mathrm{~g}, 1.34 \mathrm{mmol})$ with $95 \%$ ee, obtained by saponification of the recovered acetate $(S)-7 \mathrm{~s}$ (95\% ee) in entry 24 of Table 2 , was treated with $\mathrm{HgCl}_{2}(0.39$ $\mathrm{g}, 1.47 \mathrm{mmol})$ in $10 \% \mathrm{MeOH}(10 \mathrm{~mL})$ at reflux for $5 \mathrm{~h}$. The mixture was concentrated and extracted three times with EtOAc. The combined extracts were washed with brine, dried
( $\mathrm{Na}_{2} \mathrm{SO}_{4}$, concentrated, and separated by silica gel chromatography (EtOAc/hexane (1:9)) to give hop lactone $(0.15 \mathrm{~g}, 85 \%)$ with $[\alpha]^{25} \mathrm{D}+10^{\circ}(c=1.5, \mathrm{EtOH})$. Hop lactone in nature has been reported to have optical rotation $[\alpha]_{D}+8^{\circ}(c=0.25$, EtOH). ${ }^{1}(R)$-1s (75\% ee, entry 24 of Table 2$)$ ) was similarly converted to $(R)$-hop lactone, $[\alpha]^{25} \mathrm{D}-6.5^{\circ}(c=2.6, \mathrm{EtOH})$.

5-Butyl-4-methyl-2,3,4,5-tetrahydrofuran-2-one (Quercus Lactone) (12b). The alcohol $3 \mathrm{~b}(0.22 \mathrm{~g}, 85 \%$ ee favoring the $(2 S, 3 R)$-configuration), obtained from lipase-catalyzed hydrolysis of acetate $\mathbf{9 b}$, was treated with $\mathrm{HgCl}_{2}$ by a procedure similar to that for hop lactone to give trans quercus lactone $(153 \mathrm{mg}, 92 \%)$ in favor of $(4 S, 5 R)$-configuration $(85 \%$ ee), $[\alpha]^{25} \mathrm{D}+68^{\circ}(c=1.2, \mathrm{MeOH})\left(\right.$ lit. $^{2}[\alpha]_{\mathrm{D}}+79^{\circ}(c=1.04$, $\mathrm{MeOH}))$. Hydrolysis of $(2 R, 3 S)-3 \mathrm{~b}(95 \%$ ee) gave $(4 R, 5 S)$ quercus lactone $(95 \% \mathrm{ee}),[\alpha]^{25} \mathrm{D}-75^{\circ}(c=1.0, \mathrm{MeOH})$

5-Pentyl-4-methyl-2,3,4,5-tetrahydrofuran-2-one (Cognac Lactone) (12c). The alcohol 3c $(100 \mathrm{mg}, 94 \%$ ee favoring the $(2 S, 3 R)$-configuration), obtained from lipasecatalyzed hydrolysis of acetate $9 \mathrm{c}$, was treated with $\mathrm{HgCl}_{2}$ by a procedure silimar to that for hop lactone to give trans cognac lactone $(65 \mathrm{mg}, 92 \%)$ in favor of $(4 S, 5 R)$-configuration $(96 \%$ ee), $[\alpha]^{25} \mathrm{D}+75^{\circ}\left(c=1.0, \mathrm{CH}_{2} \mathrm{Cl}_{2}\right)$, lit. $^{3}[\alpha]_{\mathrm{D}}+79.5^{\circ}(c=1.12$, $\left.\mathrm{CH}_{2} \mathrm{Cl}_{2}\right)$. Hydrolysis of $(2 R, 3 S)-3 \mathrm{c}(37 \%$ ee) gave $(4 R, 5 S)$ cognac lactone, $[\alpha]_{D^{25}}-35^{\circ}\left(c=2.9, \mathrm{CH}_{2} \mathrm{Cl}_{2}\right)$.

Acknowledgment. We thank the National Science Council of the Republic of China for financial support (Grant NSC83-0208-M002-041).

Supplementary Material Available: NMR spectra and additional spectral data of new compounds (65 pages). This material is contained in libraries on microfiche, immediately follows this article in the microfilm version of the journal, and can be ordered from the ACS; ordering information is given on any current masthead page. 